\title{
CARBON-14 IN THE HTGR FUEL CYCLE
}

\author{
by \\ L. H. BROOKS, C. A. HEATH, \\ B. KIRSTEIN and D. G. ROBERTS
}

Prepared under Contract AT(04-3)-167 Project Agreement No. 53 for the San Francisco Operations Office U. S. Atomic Energy Commission

DATE PUBLISHED - NOVEMBER 29, 1974
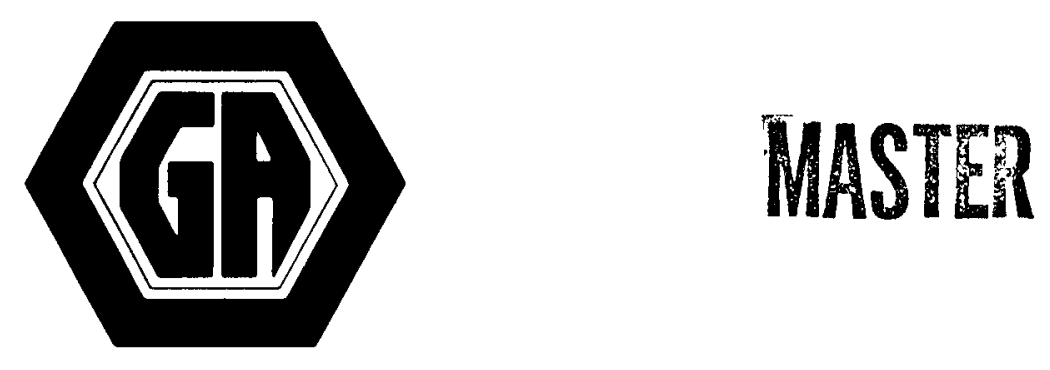


\section{NOTICE}

This report was prepared as an account of work sponsored by the United States Government. Neither the United States nor the United States Atomic Energy Commission, nor any of their employees, nor any of their contractors, subcontractors, or their employees, makes any warranty, express or implied, or assumes any legal liability or responsibility for the accuracy, completeness or usefulness of any information, apparatus, product or process disclosed, or represents that its use would not infringe privately owned rights.

Printed in the United States of America

Available from

National Technical Information Service

U.S. Department of Commerce

5285 Port Royal Road

Springfield, Virginia 22161

Price: Printed Copy $\$ 5.45$; Microfiche $\$ 4.45$ 


\section{DISCLAIMER}

This report was prepared as an account of work sponsored by an agency of the United States Government. Neither the United States Government nor any agency Thereof, nor any of their employees, makes any warranty, express or implied, or assumes any legal liability or responsibility for the accuracy, completeness, or usefulness of any information, apparatus, product, or process disclosed, or represents that its use would not infringe privately owned rights. Reference herein to any specific commercial product, process, or service by trade name, trademark, manufacturer, or otherwise does not necessarily constitute or imply its endorsement, recommendation, or favoring by the United States Government or any agency thereof. The views and opinions of authors expressed herein do not necessarily state or reflect those of the United States Government or any agency thereof. 


\section{DISCLAIMER}

Portions of this document may be illegible in electronic image products. Images are produced from the best available original document. 


\title{
CARBON-14 IN THE HTGR FUEL CYCLE
}

by

\author{
L. H. BROOKS, C. A. HEATH, \\ B. KIRSTEIN and D. G. ROBERTS
}

Prepared under

Contract AT(04-3)-167

Project Agreement No. 53

for the

San Francisco Operations Office

U. S. Atomic Energy Commission

GENERAL ATOMIC PROJECT 0852 DATE PUBLISHED - NOVEMBER 29, 1974

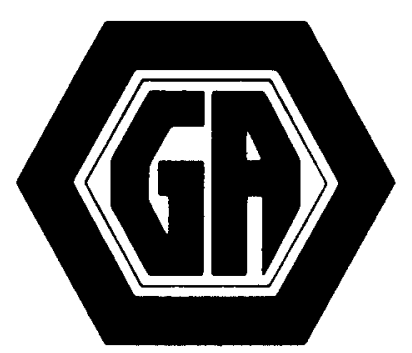

This report was prepared as an account of work sponsored by the United States Government. Neither the United States nor the United States Atomic Energy Commission, nor any of their employees, nor any of their contractors, subcontractors, or their employees, makes any warranty, express or impr their employees, legal liability or responsibility implied, or assumes any pleteness or usefulness of any for the accuracy, completeness or usefulness of any information, apparatus, product or process disclosed, or represents that its use 


\section{ABSTRACT}

There is a natural production rate of Carbon-14 which originates in the earth's atmosphere. It becomes part of all living matter and is absorbed in the ocean, where it comes to steady state concentration with the atmosphere. Because of the presence of nitrogen in high-temperature, gas-cooled reactor fuel elements, $\mathrm{C}-14$ is formed, which is released as $\mathrm{CO}_{2}$ on burning, adding more into the atmosphere. In this report the natural state of the earth's $\mathrm{C}-14$ cycle is examined and the effects of releasing man-made $\mathrm{C}-14$ to it are studied with a view toward determining the consequences that increasing the total $\mathrm{C}-14$ content in the earth will have on human health.

Carbon-14 (half-life 5730 years) is generated in the upper atmosphere at a rate of about $6 \mathrm{~kg} /$ year and maintains the quantity of $\mathrm{C}-14$ in the atmosphere at a leve1 of $954 \mathrm{~kg}$. This results in a radiation dose rate of $1.6 \mathrm{mr} /$ year. The carbon cycle transports the $\mathrm{c}-14$ into many reservoirs, the largest being the ocean, which contains $98.1 \%$ of the world's entire inventory of $50,300 \mathrm{~kg}$. Bomb tests in the $1950 \mathrm{~s}$ and early 1960s increased the mass of $\mathrm{C}-14$ in the atmosphere to $2209 \mathrm{~kg}$ at the end of 1962 . The excess mass of $1255 \mathrm{~kg}$ is being shared among the other reservoirs by the natural carbon-cycle process and will drop to $24 \mathrm{~kg}(1.9 \%)$. The rate of removal of $\mathrm{C}-14$ into the other reservoirs is calculated to have a half-1ife of 10 to 30 years based on the disappearance of the excess $\mathrm{C}-14$ from the atmosphere since 1962 .

Initial studies on $\mathrm{C}-14$ generation indicate that the level in a fuel block may be in the region of $0.16 \mathrm{Ci}$ per fuel element and will be released as $\mathrm{CO}_{2}$ during reprocessing. The annual release has been calculated knowing the reprocessing rate. It is initially $0.9 \mathrm{~kg} /$ year in 1985 and increases to $5.85 \mathrm{~kg} /$ year in 2000 , the total cumulative mass released being $50.4 \mathrm{~kg}$ 
by 2000 and $255 \mathrm{~kg}$ by 2035. Because this quantity is continually being shared among the other reservoirs, the quantity in the atmosphere is less than $255 \mathrm{~kg}$. This results in a dose rate less than $0.4 \mathrm{mr} /$ year, which is a very small dose rate compared with $1.6 \mathrm{mr} /$ year for $\mathrm{C}-14$ and $130 \mathrm{mr} /$ year for the total sea-level background.

The effect of releasing $\mathrm{C}-14$ from the reprocessing plant stack is minimized by increasing the stack height. It is calculated that the ingestion dose rate to a person at the boundary who consumes one-third of his carbon intake from locally grown vegetables is less than $5 \mathrm{mr} /$ year with a stack height of 500 feet or more.

The release of $\mathrm{CO}_{2}$ to the atmosphere from fossil fuel combustion dilutes the $\mathrm{C}-14$ and reduces the annual dose rate. The combustion of $10^{9}$ tons of fossil carbon is equivalent to $1.36 \mathrm{~kg} \mathrm{C}-14$ at atmospheric concentration. A certain quantity of $\mathrm{C}-14$, therefore, may be released without change to the environment.

Potassium-40 is unique in that it is the naturally occurring radioactive isotope of an element essential to living matter. It has a halflife of $10^{9}$ years and results in a dose rate of $20 \mathrm{mr} /$ year. This is 12 times the dose rate from natural $\mathrm{C}-14$.

Carbon-14 is also unique in that it is not only a radioactive isotope of carbon, which is a constituent of living matter, but is continually being regenerated.

The dose commitment, that is, the dose rate multiplied by the duration of the dose, has been calculated for the entire forecasted HTGR market over 50 years and found to be $7.3 \mathrm{mr}$. This compares with $6500 \mathrm{mr}$ for the background dose commitment over the same period.

It is concluded that the increase in radiation levels due to the release of $\mathrm{C}-14$ is very low compared with that of the background. 
CONTENTS

ABSTRACT . . . . . . . . . . . . . . . . . . . . . $i i i$

1. INTRODUCTION . . . . . . . . . . . . . . . . . . . . 1

2. FORMATION OF NATURAL $\mathrm{C}-14$. . . . . . . . . . . . . . . 2

3. NATURAL PRODUCTION RATE AND DECAY . . . . . . . . . . . . . 2

4. CARBON-14 IN HUMAN BODY . . . . . . . . . . . . . . . . . 2

5. PRESENT DISTRIBUTION OF $\mathrm{C}-14$ IN ENVIRONMENT . . . . . . . . . . 3

6. CARBON FLOW AMONG WORLD'S RESERVOIRS . . . . . . . . . . . . 3

7. FORMATION OF C-14 IN HTGR FUEL ELEMENTS . . . . . . . . . . . . 6

8. RELEASE OF C-14 TO ATMOSPHERE UPON BURNING HTGR FUEL

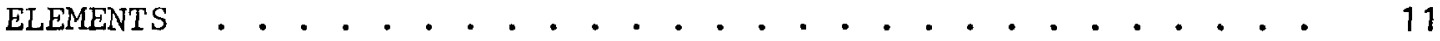

9. LIMITS ON LOCAL ENVIRONMENTAL EFFECTS IMPOSED BY FEDERAL

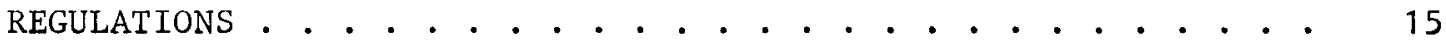

9.1. 10CFR20 .................... 15

9.2. 10CFR50 . . . . . . . . . . . . . . . . 15

10. CALCUlation OF DOSES SURROUNDING REPROCESSING PLANT . . . . . . 17

11. GLOBAL EFFECT OF ISOLATED INJECTION OF C-14 INTO ATMOSPHERE . . 21

12. GLOBAL EFFECT OF CONTINUING RELEASE OF C-14 TO ATMOSPHERE . . . 25

13. DOSE COMMITMENT . . . . . . . . . . . . . . . . . . 30

14. FUTURE POSSIBILITIES CONCERNING C-14 RELEASE . . . . . . . . . 32

15. METHODS OF FIXING $\mathrm{C}-14$. . . . . . . . . . . . . . . 33

15.1. Fixation as $\mathrm{CaCO}_{3}$. . . . . . . . . . . . . . . . 33

15.2. Burial of Fuel Block . . . . . . . . . . . . 33

16. CONCLUSIONS . . . . . . . . . . . . . . . . . . . 35

17. RECOMMENDATIONS . . . . . . . . . . . . . . . . . . . . . 38

APPENDIX A WEIGHT OF C-14 IN ATMOSPHERE AND OTHER VALUES IN 1952

(PRIOR TO BOMB TESTS) ................ . . 39

APPENDIX B. NATURAL PRODUCTION RATE OF C-14........... . 41

APPENDIX C. IMMERSION AND INGESTION DOSE RATE DUE TO C-14

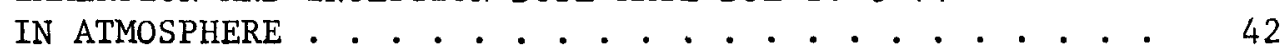

APPENDIX D. C-14 CONCENTRATION IN ATMOSPHERE AT SITE BOUNDARY . . 43 


\section{CONTENTS (Continued)}

APPENDIX E. INGESTION OF C-14 AT SITE BOUNDARY (300-FT STACK) . • 44

APPENDIX F. CALCULATION OF C-14 DOSE COMMITMENT OVER 50 YEARS . . . 45

APPENDIX G. HEALTH EFFECTS OVER 50 YEARS DUE TO C-14 RELEASE FROM HTGR REPROCESSING . . . . . . . . . . . . . . . 46

REFERENCES . • . . . . . . . . . . . . . . . . . . . . . 47

\section{FIGURES}

1. Carbon flow in reservoirs . . . . . . . . . . . . . 5

2. Design basis values of $\mathrm{C}-14$ activity in fuel element versus nitrogen content . . . . . . . . . . . . . . 10

3. Weight of $\mathrm{C}-14$ released by burning spent fuel . . . . . . . 14

4. Activity of $\mathrm{C}-14$ in air at site boundary of HTGR reprocessing plant. . . . . . . . . . . . . . . . . . 20

5. Relationship between dilution factor and stack height . . . . . . 22

6. Estimated maximum ingestion dose from $\mathrm{C}-14$ at boundary of HTGR fuel reprocessing plant using various stack heights . . . . . . 23

7. Disposition of $\mathrm{C}-14$ in atmosphere following bomb tests in $1950 \mathrm{~s}$ and $1960 \mathrm{~s}$. . . . . . . . . . . . . . . . . . 26

8. Projected rate of combustion of fossil carbon . . . . . . . . 28

9. Global Carbon-14 response . . . . . . . . . . . . . 29

\section{TABLES}

1. Distributions of natural $\mathrm{C}-14$ and excess $\mathrm{C}-14$ in carbon reservoirs at end of 1962 . . . . . . . . . . . . . . . . 4

2. C-14 determined in Magnox reactor graphite . . . . . . . . 12

3. C-14 determined in irradiated graphite samples . . . . . . . . 12

4. C-14 contained in spent fuel elements . . . . . . . . . . . . . 13

5. Routine release of radioactive materials from HTGR reprocessing plant stack . . . . . . . . . . . . . . . 19

6. Summary of maximum individual doses from routine releases, 300-ft stack . . . . . . . . . . . . . . . 24 


\section{INTRODUCTION}

This report considers the potential consequences of $\mathrm{C}-14$ being released to the environment during the combustion of spent HTGR fuel elements in a reprocessing plant. To find out what happens to the released $\mathrm{C}-14$, it is necessary to know its natural production rate and how the world C-14 concentration would be affected by a second production rate. C-14 is absorbed in sea water and is preferentially convected and diffused downward where the concentration is reduced by radioactive decay (Ref. 1). The natural $\mathrm{C}-14$, therefore, is in steady state between the biosphere (carbon in the atmosphere, in living tissue, in humus, and in the top $100 \mathrm{~m}$ of the oceans) and the carbon in the ocean below $100 \mathrm{~m}$. If the concentration of $\mathrm{C}-14$ in the atmosphere is raised by discharging $\mathrm{CO}_{2}$ from the HTGR fuel burning operations, some of the $\mathrm{C}-14$ gradually finds its way via the vegetable food chain into living tissue formed from the $\mathrm{C}-14 / \mathrm{C}-12$ mixture in the atmosphere. Most of it, however, will be absorbed directly into the deep ocean. The final disposition of manmade $\mathrm{C}-14$ will be between the biosphere and the ocean in the same ratio as natural $\mathrm{C}-14$.

The concentration of $\mathrm{C}-14$ in carbon due to natural processes is $13.5 \mathrm{dpm} / \mathrm{g}$ carbon. The present level of $21 \mathrm{dpm} / \mathrm{g}$ is due to the combined effects of natural processes and the residues from atmospheric testing of nuclear weapons. The objective of the "as low as practicable" (ALAP) regulation is to keep the release of $\mathrm{C}-14$ at a low enough value that the environment is not adversely affected.

The ramifications of $\mathrm{C}-14$ are discussed and a method for achieving the ALAP criterion is recommended. 


\section{FORMATION OF NATURAL C-14}

C-14 is formed in the outer atmosphere of the earth by the interaction of $\mathrm{N}-14$ with neutrons formed by cosmic radiation, and is oxidized by an unknown mechanism to $\mathrm{CO}_{2}$ (Ref. 1). The $\mathrm{CO}_{2}$ diffuses and convects throughout the atmosphere and enters into the carbon cycle (see Section 5). Measurements made on bristlecone pine show the production of $\mathrm{C}-14$ has been occurring for thousands of years and probably for millions of years (Ref. 2). The mass of C-14 in the atmosphere, calculated to be $954 \mathrm{~kg}$, is derived in Appendix A.

\section{NATURAL PRODUCTION RATE AND DECAY}

The natural production rate is calculated to be $6.4 \mathrm{~kg} / \mathrm{yr}$ (Refs. 3,4), but this number depends upon the basic quantities used in the calculation, which is given in Appendix B. The basic quantities are the concentration of $\mathrm{C}-14$ in carbon, taken to be $13.5 \mathrm{dpm} / \mathrm{g}$ in the atmosphere and less in the ocean, and the total amount of carbon in the world's reservoirs, taken to be $42 \times 10^{15} \mathrm{~kg}$.

The rate of decay must equal the rates of production because the change in concentration over thousands of years has been trivial (Ref. 1). The flow of $\mathrm{C}-14$ is from the outer atmosphere, down to sea level, into living tissue, and finally into the deep sea where it is removed by radioactive decay.

\section{CARBON-14 IN HUMAN BODY}

The human body is exposed to radiation from $\mathrm{C}-14$ by immersion and by ingestion. Radiation by immersion occurs to the skin. The weak beta has virtually no penetration power and the dose rate is 1 ow at $0.0034 \mathrm{mr} / \mathrm{yr}$ (Appendix C) when the atmospheric concentration is $2.17 \times 10^{-13} \mathrm{~g} / \mathrm{cm}^{3}$ (Appendix A). 
Exposure by ingestion occurs because the human body contains carbon taken from the carbon cycle, which is at equilibrium with the atmosphere. Since the average body contains $13 \mathrm{~kg}$ of carbon, it contains $1.8 \times 10^{-8} \mathrm{~g}$ of $\mathrm{C}-14$. This produces a radiation dose of $1.64 \mathrm{mr} / \mathrm{yr}$ to the human body. It can be seen, therefore, that eating food containing a larger fraction of $\mathrm{C}-14$ in the carbon will create a larger dose rate in the body.

An increase in $\mathrm{C}-14$ concentration in carbon will proportionately cause an increase in the annual dose rate.

\section{PRESENT DISTRIBUTION OF C-14 IN ENVIRONMENT}

In a paper written in 1969 (Ref. 1), A. W. Fairhall and J. A. Young presented the distribution of natural $\mathrm{C}-14$ and of excess $\mathrm{C}-14$ that had been added to the atmosphere due to testing of nuclear weapons. This data is given in Table 1. They indicated nuclear testing in the 1950s added approximately $550 \mathrm{~kg}$ of $\mathrm{C}-14$ to the $953 \mathrm{~kg}$ already in the atmosphere. In addition, the tests performed in 1961 and 1962 added an additional $706 \mathrm{~kg}$ so that a so-called excess of $\mathrm{C}-14$ amounting to $1256 \mathrm{~kg}$ was added to the environment. While this represented more than twice the pre-existing levels of $\mathrm{C}-14$ in the atmosphere, it was an addition of only $2.5 \%$ to the total amount of $\mathrm{C}-14$ in the terrestrial environment.

For purposes of comparison, the quantity in the atmosphere prior to 1950 was $953 \mathrm{~kg}$ of $\mathrm{C}-14$. The total quantity of $\mathrm{C}-14$ in the atmosphere shown at the end of 1962 is equivalent to $9.94 \times 10^{6}$ curies or $2209 \mathrm{~kg}$. By 1965, the total inventory in the atmosphere had fallen to $1765 \mathrm{~kg}$. In 1974, the count of $21 \mathrm{dpm} / \mathrm{g} \mathrm{C}$ indicates the quantity to be $1482 \mathrm{~kg}$.

\section{CARBON FLOW AMONG WORLD'S RESERVOIRS}

A simplified diagram showing the world's carbon reservoirs, shown in Fig. 1, is taken from the work of Cramer (Ref. 4). Carbon flows in the direction of the arrows into the reservoirs, which are of different sizes measured in terms of weight of carbon. Some arrows show carbon transfers that are rapid and others transfers that are slow. 
TABLE 1

DISTRIBUTIONS OF NATURAL C-14 AND EXCESS C-14 IN CARBON RESERVOIRS AT END OF 1962 (REF. 1)

\begin{tabular}{l|c|c|c|c}
\hline \multicolumn{1}{c|}{ Reservoir } & $\begin{array}{c}\text { Tota1 } \\
\text { Carbon } \\
\left(\mathrm{g} \times 10^{18}\right)\end{array}$ & $\begin{array}{c}\text { Pre-1950 C-14 } \\
\text { Concentration } \\
(\mathrm{g} / \mathrm{g} \text { Carbon } \\
\left.\mathrm{x} 10^{-15}\right)\end{array}$ & $\begin{array}{c}\text { Total } \\
\text { Natura1 } \\
\text { C-14 (1952) } \\
\left(\mathrm{g} \times 10^{3}\right)\end{array}$ & $\begin{array}{c}\text { Total (a) } \\
\text { Excess } \\
\mathrm{C}-14(1962) \\
\left(\mathrm{g} \times 10^{3}\right)\end{array}$ \\
\hline Atmospheric & 0.68 & 1.41 & 953 & 1256 \\
Terrestrial biosphere & 0.31 & 1.36 & 418 & $<20$ \\
Humus & 1.1 & $1.35(\mathrm{~b})$ & $<1,490$ & $<20$ \\
$\begin{array}{l}\text { Dissolved organic } \\
\text { in sea }\end{array}$ & 0.8 & $1.23(\mathrm{c})$ & 977 & $<<20$ \\
$\begin{array}{l}\text { Inorganic carbon } \\
\text { in sea: }\end{array}$ & 1.0 & 1.35 & 1,349 & $\sim 70$ \\
Top 100 meters & 38.0 & 1.19 & 45,116 & $\sim 20$ \\
\hline $\begin{array}{l}\text { Below 100 meters } \\
\text { Al1 reservoirs }\end{array}$ & 42.0 & & 50,300 & $\sim 1395$ \\
\hline
\end{tabular}

Percentage of total $\mathrm{C}-14$ distributed in the atmospheric reservoir $=1.9 \%$

(a) Excess due to atmospheric bomb tests in 1950s and 1962-63.

(b) Average age of humus is unknown.

(c) Age of dissolved organic matter in sea is unknown, but total amount present compared with estimated rate of production suggests accumulation over many hundreds of years. 


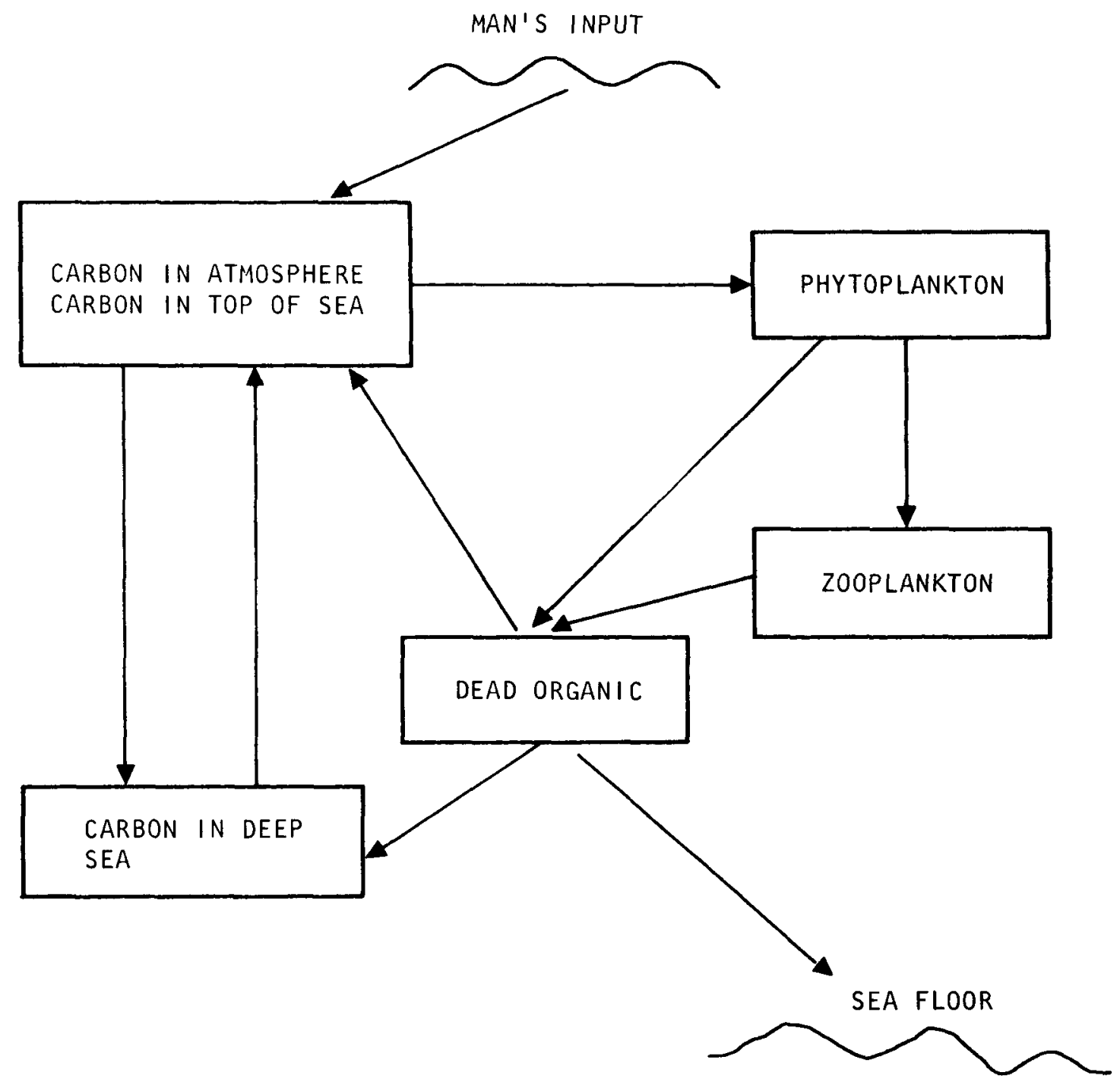

Fig. 1. Carbon flow in reservoirs 
C-14 is injected naturally at a virtually constant rate and is removed at the same rate. Carbon is lost for long periods when limestone settles on the ocean floor. Carbon-12 is being injected by man with the combustion of fossil carbonaceous fuels. The flow of carbon around the cycle is affected by the injections and loss, but tries to regain steady state.

The injection of $\mathrm{C}-14$ released from reprocessing HTGR fuels has an effect, and an attempt is made to forecast it in Section 12.

\section{FORMATION OF C-14 IN HTGR FUEL ELEMENTS}

C-14 is produced in the HTGR fuel element by the following neutron reactions :

$$
\begin{aligned}
& \text { 1. }{ }^{14} \mathrm{~N}(\mathrm{n}, \mathrm{p}){ }^{14} \mathrm{C} \\
& \text { 2. }{ }^{13} \mathrm{C}(\mathrm{n}, \gamma){ }^{14} \mathrm{C} \\
& \text { 3. }{ }^{17} \mathrm{O}(\mathrm{n}, \alpha){ }^{14} \mathrm{C}
\end{aligned}
$$

Nitrogen is contained in the fuel element in small quantities due to its processing history. This nitrogen is present either in adsorbed form in the graphite material, as chemically bound, or as elemental nitrogen entrapped in voids in the fuel element material. The nitrogen that is transformed into $\mathrm{C}-14$ is the residual nitrogen remaining in the fuel element after loosely bound nitrogen has been desorbed into the coolant circuit and gettered in the coolant cleanup system. C-13 occurs naturally in a11 carbon material with an abundance of $1.11 \%$. The third contributor, Oxygen-17, is contained in the oxide fuel particles. However, the amount of $\mathrm{C}-14$ due to $0-17$ in the fuel element is negligible because of the low concentration of $0-17$ in $0-16$.

Early calculations of the C-14 concentration in spent fuel elements coming from an HTGR were based on conservative and somewhat arbitrary 
assumptions concerning both the neutron cross sections of the materials involved and the quantity of nitrogen contained in the fuel element. Specification of the amount of activation products in the fuel element had been prepared primarily for determining design criteria for the helium coolant loops in the operating reactor. These design criteria were set rather high so that expected coolant loop activities could be easily handled if the design met intended criteria. Early calculations were based on the assumption that the thermal neutron cross section for both $\mathrm{C}-13$ and $\mathrm{N}-14$ was energy independent up to $2.38 \mathrm{eV}$ (Ref. 5). It was a1so assumed that the cross sections were equal to their $2200 \mathrm{M} / \mathrm{sec}$ value. These assumptions resulted in significant overestimation of the C-14 produced. In addition, it was assumed, somewhat arbitrarily, that the nitrogen contamination in an HTGR fuel element would be $100 \mathrm{ppm}$ and that none would be desorbed in the reactor. Experimental analysis performed in 1972 on fuel elements from the Ft. St. Vrain production run indicated the total nitrogen concentration in an HTGR fuel element containing $\mathrm{ThC}_{2}$ fertile particles would be below $30 \mathrm{ppm}$ (Ref.6).

The above assumptions resulted in a calculation of 1.09 curies of C-14 per spent fuel element coming from a large HTGR. Of this amount, 0.05 curie was due to the $\mathrm{C}-13$ source and 1.04 curies were due to the $\mathrm{N}-14$ source. More recent calculations and data indicate a value closer to 0.2 curie. The history of this determination is described below.

In the fall of 1973, when the Idaho Chemical Programs Office of Allied Chemical Corporation was preparing an environmental impact statement for the demonstration reprocessing plant to be built at the National Reactor Testing Station, the source terms for C-14 from an HTGR fuel element were supplied by General Atomic. They were subsequently used in the environmental impact statement, which has recently been issued as WASH- 1534 .

In December 1973, work was being done at Oak Ridge National Laboratory in the preparation of a chapter to be submitted as part of a draft environmental survey of the HTGR fuel cycle being compiled by the Director of 
Regulation, AEC. At that time, J. Snider of Oak Ridge National Laboratory investigated in detail the basis for the source terms used for the estimation of $\mathrm{C}-14$ in the HTGR fuel element. As a result of his investigation, it was discovered that the neutron cross sections used in determining this value were unreasonably high. New calculations of the neutron absorption cross sections of $\mathrm{C}-14$ and $\mathrm{N}-14$ have been done allowing for a $1 / \mathrm{V}$ energy dependence up to a cutoff energy of $2.38 \mathrm{eV}$. The cross sections used in the new calculations are as follows:

$$
\begin{aligned}
& c^{13}: \sigma(n, \gamma)=0.9 \mathrm{mb} \pm 0.2 \mathrm{mb} \text { at } 2200 \mathrm{M} / \mathrm{sec} \\
& \mathrm{N}^{14}: \sigma(n, \rho)=1.81 \mathrm{~b} \pm 0.05 \mathrm{~b} \text { at } 2200 \mathrm{M} / \mathrm{sec}
\end{aligned}
$$

Applying the $1 / \mathrm{V}$ assumption with a thermal cut-off energy of $2.3 \mathrm{eV}$, the following cross sections can be determined in a typical HTGR spectrum:

$$
\begin{aligned}
& \mathrm{C}^{13}: \sigma(\eta, \gamma)=0.34 \mathrm{mb} \pm 0.075 \mathrm{mb} \text { at } 0-2.38 \mathrm{eV} \\
& \mathrm{N}^{14}: \sigma(\eta, \rho)=0.683 \mathrm{~b} \pm 0.019 \mathrm{mb} \text { at } 0-2.38 \mathrm{eV}
\end{aligned}
$$

Using these cross sections, the C-14 produced after four years of exposure with an assumed $100 \mathrm{ppm} \mathrm{N-14} \mathrm{Impurity} \mathrm{level} \mathrm{is} \mathrm{calculated} \mathrm{as}$ follows:

$$
\begin{aligned}
& c^{13}(\eta, \gamma) c^{14}: 2.0 \times 10^{-2} \frac{\text { curies }}{\text { block }}=0.45 \times 10^{-2} \frac{\text { grams }}{\text { block }} \\
& \mathrm{N}^{14}(\eta, \rho) \mathrm{C}^{14}: \quad 39 \times 10^{-2} \frac{\text { curies }}{\text { block }}=8.7 \times 10^{-2} \frac{\text { grams }}{\text { block }} \\
& \text { at } \frac{N^{14}}{C^{12}}=10^{-4} \\
& \text { Tota1 expected: } 41 \times 10^{-2} \frac{\text { curies }}{\text { block }}=9.1 \times 10^{-2} \frac{\text { grams }}{\text { block }} \\
& \text { at } \frac{\mathrm{N}^{14}}{\mathrm{c}^{12}}=10^{-4}
\end{aligned}
$$


A11 of the above source terms may be categorized as the expected values. For purposes of design, a design basis has been defined to allow for uncertainties. The uncertainty is in the thermal flux level. Calculational uncertainty in flux is expected to be small $( \pm 5 \%)$, but cyclic variations and system flexibility lead to flux levels as high as $1.3 \times 10^{14} \mathrm{~N} / \mathrm{cm}^{2}-\mathrm{sec}$. By adding the fractional uncertainty in both cross section and flux, a margin of $50 \%$ for the $\mathrm{C}-13$ reaction and $30 \%$ for the N-14 reaction is obtained. The design basis is therefore as follows:

$$
\begin{gathered}
\mathrm{C}^{13}(\eta, \gamma) \mathrm{C}^{14}: 3.0 \times 10^{-2} \frac{\text { curies }}{\text { block }}=0.69 \times 10^{-2} \frac{\text { grams }}{\text { block }} \\
\mathrm{N}^{14}(\eta, \rho) \mathrm{C}^{14}: 50 \times 10^{-2} \frac{\text { curies }}{\text { block }}=11 \times 10^{-2} \frac{\text { grams }}{\text { block }} \\
\text { at } \frac{N^{14}}{C^{12}}=10^{-4} \\
\text { Tota1: } 53 \times 10^{-2} \frac{\text { curies }}{\text { block }}=12 \times 10^{-02} \frac{\text { grams }}{\text { block }} \frac{\mathrm{N}^{14}}{C^{12}}=10^{-4}
\end{gathered}
$$

It should be noted that the above source terms are equivalent to an assumed nitrogen concentration of $100 \mathrm{ppm}$, which remains in the fuel element for 4 years of average reactor operation. The above information was used to prepare the graph in Fig. 2. As previously discussed, measurements taken in 1972 on reject fuel elements for the Fort St. Vrain reactor indicated the total nitrogen content in the HTGR fuel element, before insertion in the reactor, to be below $30 \mathrm{ppm}$. However, these results are considered preliminary. Additional data are being determined. Fuel and graphite samples will be crushed to determine the free nitrogen gas liberated upon crushing and the adsorbed gas driven off when the crushed materials are heated.

Although the concentration of nitrogen in the fuel components is important in the production of $\mathrm{C}-14$, what matters more is the amount that remains in the fuel element and is irradiated. The nitrogen lost from the fuel element by degassing is of no consequence in $\mathrm{C}-14$ production. 


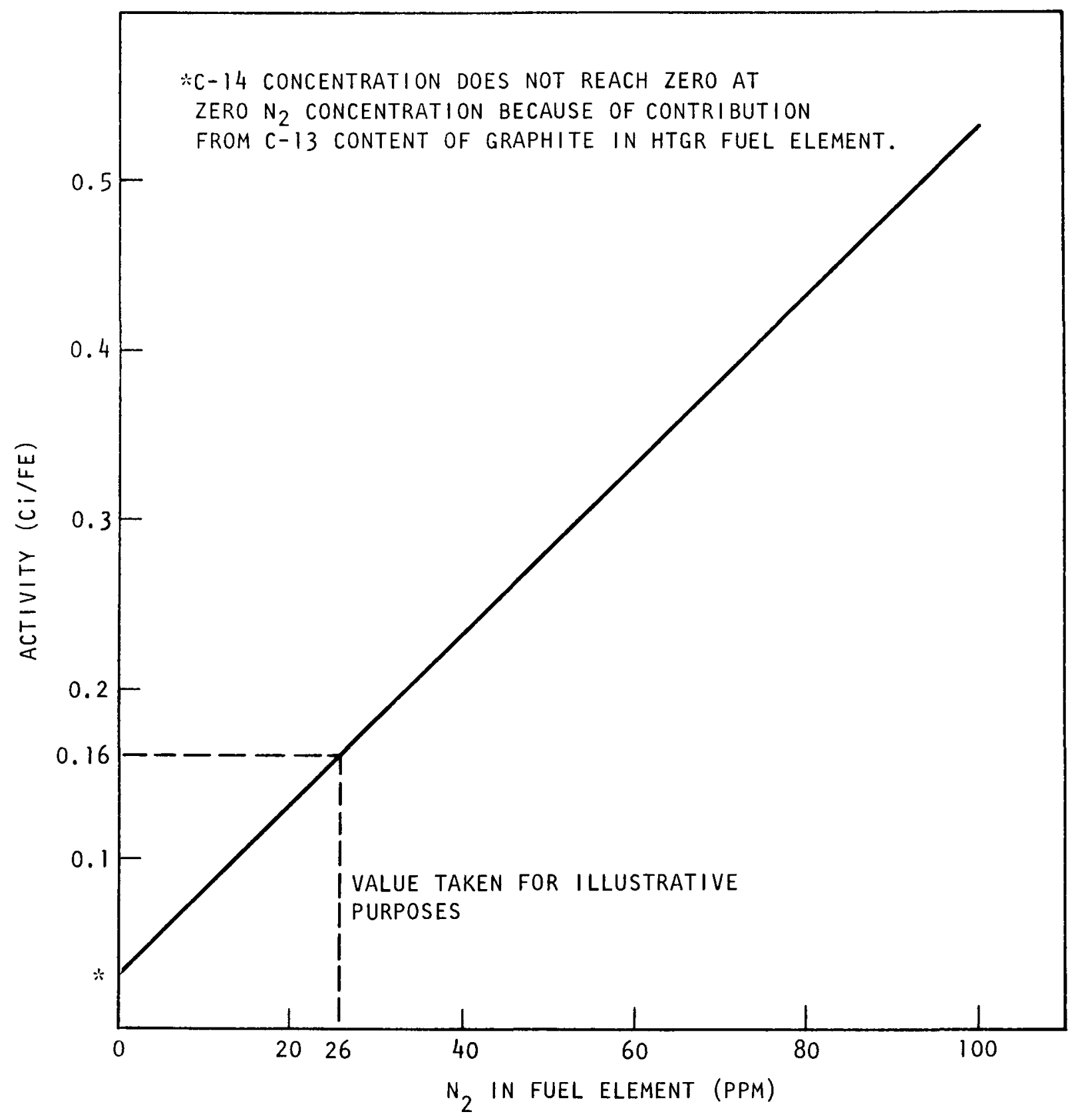

Fig. 2. Design basis values of $\mathrm{C}-14$ activity in fuel element versus nitrogen content 
The actual amount of $\mathrm{C}-14$ generated is best determined by measurement of $\mathrm{C}-14$ after irradiation; two values have been found (Refs. 7, 8). They are listed in Tables 2 and 3.

These measured values indicate that the $\mathrm{C}-14$ that can be expected from graphite is quite low. No results are available at the present time for $\mathrm{C}-14$ in the other fuel components. Mosen determined the quantity of nitrogen out-gassed from fuel particles up to $3000^{\circ} \mathrm{C}$ and obtained a range lying between 140 and $683 \mathrm{ppm}$ (Ref. 9). The interesting quantity, however, is the residual amount; i.e., that evolved above $1200^{\circ} \mathrm{C}$ (particle operating temperature), which was not determined.

Since there is at present so much doubt about the residual quantity of nitrogen in a fuel element that will eventually be converted to C-14, a figure of $26 \mathrm{ppm}$ has been taken for illustrative purposes for this document (see Fig. 2), but when the results of analysis become available, the numbers will be modified to be consistent with the new data. The $\mathrm{C}-14$ content of the spent HTGR fuel element containing this quantity of $\mathrm{N}_{2}$ is expected to be less than 0.2 curie.

\section{RELEASE OF C-14 TO ATMOSPHERE UPON BURNING HTGR FUEL ELEMENT}

The amount of $\mathrm{C}-14$ released during reprocessing depends on the number of fuel elements processed, but for consistency a representative market penetration is used. Table 4 contains the calculated data.

The release of $\mathrm{C}-14$ to the atmosphere is moderately well represented by the equation

$$
\text { Weight of } \mathrm{c}-14 \text { released }(\mathrm{kg} / \mathrm{yr})=0.36 \mathrm{t}+0.44 \text {, }
$$

where $\mathrm{t}=$ years starting at 1985 ,

$$
=0 \text {. }
$$

The graph is shown in Fig. 3. 
TABLE 2

C-14 DETERMINED IN MAGNOX REACTOR

GRAPHITE (REF. 7)

\begin{tabular}{c|c}
\hline Amount & $\begin{array}{c}\text { N-14 Equivalent } \\
(\mathrm{ppm})\end{array}$ \\
\hline $1.5 \times 10^{-8} \mathrm{Ci} / \mathrm{g} \cdot \mathrm{yr} \cdot 10^{13} \mathrm{nvt}$ & 6 \\
\hline
\end{tabular}

TABLE 3

C-14 DETERMINED IN IRRADIATED

GRAPHITE SAMPLES (REF. 8)

\begin{tabular}{c|c|c|c}
\hline $\begin{array}{c}\text { Graphite } \\
\text { Type }\end{array}$ & $\begin{array}{c}\text { Irradiation } \\
\text { Temp. }\left({ }^{\circ} \mathrm{C}\right)\end{array}$ & $\begin{array}{c}\mathrm{C}-14 \\
(\mathrm{Ci} / \mathrm{B} 1 \text { ock })\end{array}$ & $\begin{array}{c}\mathrm{N}-14 \\
\text { Equivalent } \\
(\mathrm{ppm})\end{array}$ \\
\hline $\mathrm{H}-327$ & 650 & 0.089 & 12 \\
$\mathrm{H}-327$ & 950 & 0.059 & 6 \\
$\mathrm{H}-451$ & 650 & 0.089 & 12 \\
$\mathrm{H}-451$ & 1150 & 0.064 & 7 \\
\hline
\end{tabular}


TABLE 4

C-14 CONTAINED IN SPENT FUEL ELEMENTS

(26 ppm $\mathrm{N}_{2} /$ block $\equiv 0.16 \mathrm{Ci} / \mathrm{block}$ )

\begin{tabular}{|c|c|c|c|}
\hline Year & $\begin{array}{l}\text { Fuel Elements } \\
\text { Reprocessed }\left(10^{3}\right)\end{array}$ & $\begin{array}{l}\text { Ci released/ } \\
\sec \left(10^{-4}\right) \text { (a) }\end{array}$ & $\begin{array}{c}\mathrm{C}-14 \mathrm{released} / \mathrm{yr} \\
(\mathrm{kg})\end{array}$ \\
\hline 1985 1st plant (b) & 25 & 1.58 & 0.90 \\
\hline 1986 & 30 & 1.90 & 1.08 \\
\hline 1987 & 32 & 2.03 & 1.15 \\
\hline 1988 & 41 & 2.60 & 1.47 \\
\hline 1989 & 52 & 3.30 & 1.87 \\
\hline 1990 2nd plant on-line & 61 & 3.87 & 2.19 \\
\hline 1991 & 71 & $4 \cdot 50$ & 2.55 \\
\hline 1992 & 78 & 4.95 & 2.80 \\
\hline 1993 & 89 & 5.64 & 3.19 \\
\hline 1994 & 100 & 6.34 & 3.58 \\
\hline 19953 rd plant on-1ine & 114 & 7.23 & 4.09 \\
\hline 1996 & 123 & 7.80 & 4.41 \\
\hline 1997 & 133 & 8.43 & 4.77 \\
\hline 1998 & 141 & 8.94 & 5.06 \\
\hline 1999 & 152 & 9.64 & 5.45 \\
\hline 2000 & 163 & 10.33 & 5.85 \\
\hline & & & 50.41 \\
\hline
\end{tabular}

(a) 292 days/yr.

(b) Assume each plant can reprocess 57,500 fuel elements/year. 


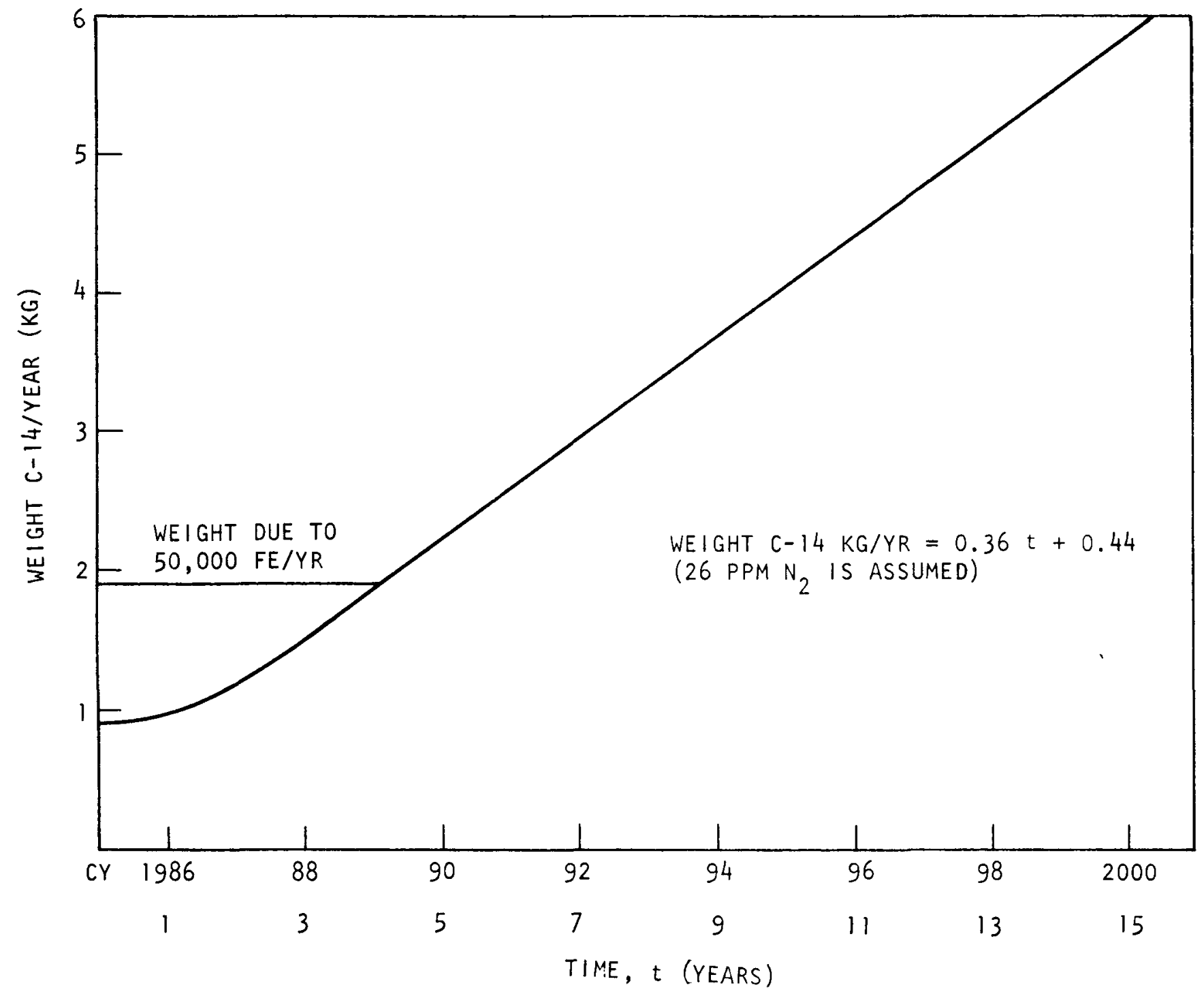

Fig. 3. Weight of C-14 released by burning spent fuel (for representative market penetration, see Table 4) 


\section{LIMITS ON LOCAL ENVIRONMENTAL EFFECTS IMPOSED BY FEDERAL REGULATIONS}

The amount of radioactivity that may be released from facilities licensed by the AEC is covered by Federal Regulations 10CFR20 and 10CFR50.

\subsection{CFR20}

Part 20 of Title 10 of the Code of Federal Regulations covers standards for protection against radiation hazards arising out of activities under licenses issued by the Atomic Energy Commission. It defines allowable levels of radioactivity in effluents to unrestricted areas. For our purposes, the concentration limits specified in Appendix $B$, Table 2 of 10CFR20 app1y at the boundary of the HTGR fuel recycle plant. This table indicates a maximum permissible concentration of $\mathrm{C}-14$ in air of $1 \times 10^{-7} \mu \mathrm{Ci} / \mathrm{ml}$. In addition, a notation indicates that $1 \times 10^{-6} \mu \mathrm{Ci} / \mathrm{m} 1$ are allowable in $\mathrm{CO}_{2}$ for immersion in a semispherical infinite cloud of airborne material. Because the $\mathrm{C}-14$ released from the reprocessing plant wi11 be in the form of $\mathrm{CO}_{2}, 10^{-6} \mu \mathrm{Ci} / \mathrm{ml}$ is the pertinent value. A further restriction in Paragraph 20.105 indicates a maximum permissible dose due to radiation in unrestricted areas of $0.5 \mathrm{rem} / \mathrm{yr}$, or $100 \mathrm{mr}$ in any seven consecutive days, or $2 \mathrm{mr}$ in any one hour.

\subsection{CFR50}

Part 50 of Title 10 of the Code of Federal Regulations covers licensing of production and utilization facilities. In 1971 the Atomic Energy Commission proposed to issue an Appendix I to 10CFR50 which would specify design objectives and limiting conditions for operation to meet the criteria "as low as practicable" for radioactive material in lightwater-cooled nuclear power reactor effluents. While this proposed rule was formulated specifically for light-water reactors, it or a similar rule might be applied to both gas-cooled reactors and nuclear fuel reprocessing plants. 
Regulation 10CFR50 has already been amended to include the requirement that the average annual release of radioactive material in effluents will be kept at sma11 percentages of the limits specified in 10CFR20 and in the operating 1icense. In addition, Paragraph 50.36 indicates that a licensee must exert his best efforts to keep levels of radioactive material in effluents as low as practicable. This term is defined as "low-aspracticable achievable taking into account the state of technology, and the economics of improvements in relation to benefits to public health and safety and in relation to the utilization of atomic energy in the public interest" and that the "resultant exposures to individuals off-site would not be expected to exceed $5 \mathrm{mr} / \mathrm{yr}$." The proposed Appendix I sets a requirement that, for gaseous effluents, the estimated total quantities of radioactive material to be released to unrestricted areas by al1 1ightwater-cooled nuclear power reactors at a site should not result in an annual average exposure rate in excess of $10 \mathrm{mr} / \mathrm{yr}$ at the site boundary. This calculation is to assume that a hypothetical individual is continuously present in the open at any location on the boundary of the site. In addition, the average annual concentration at any location on the boundary of the site has been reduced from the levels specified in 10CFR 20 by a factor of $10^{5}$ for radioactive iodines and radioactive material in particulate form with a half-life greater than eight days. Since C-14 does not concentrate in the body and is not particulate, it does not come within the $10^{5}$ restriction. Thus the site-boundary concentration should not cause an exposure by immersion to an individual off-site of greater than $5 \mathrm{mr}$; i.e., $1.435 \times 10^{-9} \mu \mathrm{Ci} / \mathrm{ml}$ (see Appendix $\mathrm{C}$ ). If, however, the person comes to steady state with the $\mathrm{C}-14$ in the atmosphere at the boundary by eating nothing but locally-produced vegetables, milk, and meat, he will receive an ingestion exposure of $5 \mathrm{mr} / \mathrm{yr}$ at an atmospheric $\mathrm{C}-14$ concentration of $2.96 \times 10^{-12} \mu \mathrm{Ci} / \mathrm{ml}$ (see Appendix C). This standard method of calculating ingestion doses has been used for I-131 and I-133. The analogy between iodine and carbon is that each element exchanges with the element already in the body and approaches the new steady state. For $\mathrm{C}-14$, the ingestion dose rate is very much larger (factor of 500) than the immersion dose rate, so the latter can be neglected. 
10. CALCULATION OF DOSES SURROUNDING REPROCESSING PLANT

The amount of radiochemical material released to the environment by a reprocessing plant depends on the throughput of the plant, and the site boundary concentration depends on the distance of the boundary from the stack and the stack height.

The reference HTGR reprocessing plant reaches a maximum throughput of 57,500 fuel elements per year. This represents a heavy-metal flow-rate of 518 tonnes/yr. When the plant is operating at capacity, the next plant is assumed to come on-1ine at a time shown in Table 4 . Site boundary concentration calculations, therefore, apply to each plant, which is assumed to be located a long distance away from the other plants to avoid site boundary interaction.

The site area is assumed to be 500 acres $\left(2 \times 10^{6} \mathrm{~m}^{2}\right)$ with the stack located centrally. The distance to the boundary is then approximately $800 \mathrm{~m}$.

The stack height is taken to be $100 \mathrm{~m}$ in the calculations involving the dilution factor $\left(7 \times 10^{-8} \mathrm{sec} / \mathrm{m}^{3}\right)$ but the effect of increasing the height is discussed later in this section.

Some preliminary calculations on the doses due to immersion and ingestion of various radioisotopes at the boundary of a reprocessing plant have been performed at ORNL (Ref. 10). The effect of stack height is considered. A summary of the work is given below.

To determine which radioisotope would be present in the stack gases, and their concentrations, 88 chemical elements (700 radioisotopes) were examined. The buildup and decay of each of these isotopes during irradiation and storage and their possible release at the reprocessing plant were studied. An ORNL computer code called ORIGEN, which contains all known information of HTGR fission product yields and the half-lives and 
decay products of these fission products, was used for these calculations.* The reliability of the ORIGEN code has been verified by irradiation samples at ORNL (Ref. 11).

Having identified these isotopes, stack gas concentrations were calculated for both nonvolatiles and semivolatiles by using a facility release factor. The facility release factors are the staff's best estimate of the fraction of a given element that will be released to the atmosphere considering all process steps. The nonvolatile release factors varied from $10^{-7}$ to $10^{-9}$ while the semivolatile elements varied from $10^{-5}$ to $10^{-7}$. This is a conservative estimate because, for semivolatiles, present LWR reprocessing facilities already achieve a minimum of $10^{-8}$, and more recent analyses indicate that $10^{-9}$ is a more accurate figure. A low factor was chosen since HTGR reprocessing development is only now in the developmenta1 stage.

Volatile (gaseous) releases calculated on the basis of decontamination factors anticipated from experimental work were $10^{3}$ for $\mathrm{H}-3,10^{4}$ for $\mathrm{I}_{2}$ isotopes, and $10^{0}$ for $\mathrm{C}-14$ (i.e., a11 C-14 is released). The results of these calculations are discussed below and presented with 10CFR20 standards for comparison in Table 5 .

The $\mathrm{C}-14$ value has been used to calculate the site boundary concentration. Use of the staff-calculated value for $X / Q\left(7 \times 10^{-8} \mathrm{~s} / \mathrm{m}^{3}\right)$ for release from a 300-ft stack shows that the radioisotope concentrations do not exceed 10CFR Part 20 or Part 50 standards for immersion at the maximum ground level concentration at the site boundary (see Appendix D and Fig. 4).

In order to calculate the ingestion dose, the model used is similar to the standard method used for iodine. Assuming that a man ingests $33 \%$ of his carbon from food grown at the site boundary (via vegetables, milk, and meat), and the vegetation is at steady state with the $C-14$ concentration

* The latest information of the ORNL Nuclear Data Center for these yields, half-lives and decay products was used in the ORIGEN code. 
TABLE 5

ROUTINE RELEASE OF RADIOACTIVE MATERIALS FROM HTGR REPROCESSING PLANT STACK

(Expected technology of the 1980s)

\begin{tabular}{|c|c|c|c|c|}
\hline $\begin{array}{l}\text { Activity } \\
\text { Released }\end{array}$ & $\begin{array}{c}\text { Average Daily } \\
\text { Release Rate } \\
(\mu \mathrm{Ci} / \text { day })\end{array}$ & $\begin{array}{c}\text { Maximum } \\
\text { Off-Site } \\
\text { Concentration } \\
(\mu \mathrm{C} i / \mathrm{m} 1)\end{array}$ & $\begin{array}{c}\text { 10CFR 20 } \\
\text { Limit } \\
(\mu \mathrm{Ci} / \mathrm{ml})\end{array}$ & $\begin{array}{l}\% \text { of } \\
\text { 10CFR20 } \\
\text { Limit }\end{array}$ \\
\hline $\begin{array}{l}\mathrm{H}-3 \\
\mathrm{C}-14 \\
\mathrm{Kr}-85 \\
\mathrm{Sr}-89 \\
\mathrm{Sr}-90 \\
\mathrm{Y}-90 \\
\mathrm{Y}-91 \\
\mathrm{Zr}-95 \\
\mathrm{Nb}-95 \\
\mathrm{Ru}-103 \\
\mathrm{Ru}-106 \\
\mathrm{Ag}-110 \mathrm{~m} \\
\mathrm{I}-129 \\
\mathrm{I}-131 \\
\mathrm{Cs}-134 \\
\mathrm{Cs}-137 \\
\mathrm{Ce}-141 \\
\mathrm{Ce}-144 \\
\mathrm{Pu}-238 \\
\mathrm{Pu}-241 \\
\mathrm{Cm}-242 \\
\mathrm{Cm}-244 \\
\text { Uranium } \\
\text { Thorium }\end{array}$ & $\begin{array}{c}41 \\
27(\mathrm{~b}) \\
10^{5} \\
50 \\
80 \\
80 \\
50 \\
80 \\
100 \\
50 \\
200 \\
0.5 \\
20 \\
2 \\
800 \\
400 \\
50 \\
400 \\
2 \\
1 \\
0.2 \\
0.2 \\
0.02 \\
0.02\end{array}$ & $\begin{array}{lll}3 & \times & 10^{-11} \\
2 & \times & 10^{-11} \\
8 & \times & 10^{-8} \\
4 & \times & 10^{-17} \\
7 & \times & 10^{-17} \\
7 & \times & 10^{-17} \\
4 & \times & 10^{-17} \\
7 & \times & 10^{-17} \\
1 & \times & 10^{-16} \\
4 & \times & 10^{-17} \\
1 & \times & 10^{-16} \\
4 & \times & 10^{-19} \\
2 & \times & 10^{-17} \\
2 & \times & 10^{-18} \\
7 & \times & 10^{-16} \\
3 & \times & 10^{-16} \\
4 & \times & 10^{-17} \\
3 & \times & 10^{-16} \\
2 & \times & 10^{-18} \\
1 & \times & 10^{-18} \\
2 & \times & 10^{-19} \\
2 & \times & 10^{-19} \\
2 & \times & 10^{-20} \\
2 & \times & 10^{-20}\end{array}$ & $\begin{array}{lll}4 & \times & 10^{-5} \\
1 & \times & 10^{-6} \\
3 & \times & 10^{-7} \\
3 & \times & 10^{-10} \\
2 & \times & 10^{-11} \\
3 & \times & 10^{-9} \\
1 & \times & 10^{-9} \\
1 & \times & 10^{-9} \\
3 & \times & 10^{-9} \\
3 & \times & 10^{-9} \\
2 & \times & 10^{-10} \\
3 & \times & 10^{-10} \\
2 & \times & 10^{-11} \\
1 & \times & 10^{-10} \\
4 & \times & 15^{-10} \\
5 & \times & 10^{-10} \\
5 & \times & 10^{-9} \\
2 & \times & 10^{-10} \\
7 & \times & 10^{-14} \\
3 & \times & 10^{-12} \\
4 & \times & 10^{-12} \\
3 & \times & 10^{-13} \\
9 & \times & 10^{-13} \\
2 & \times & 10^{-14}\end{array}$ & $\begin{array}{c}2 \times 10^{-3} \\
2 \times \\
26 \\
3 \times 10^{-4} \\
-- \\
-- \\
-- \\
-- \\
-- \\
-- \\
-- \\
1 \times 10^{-4} \\
-- \\
2 \times 10^{-4} \\
-- \\
2 \times 10^{-4} \\
3 \times 10^{-3} \\
-- \\
-- \\
-- \\
1 \times 10^{-4}\end{array}$ \\
\hline
\end{tabular}

(a) Less than $10^{-4 \%}$.

(b) Based upon assumed value of $26 \mathrm{ppm}$ nitrogen in fuel element.

(See Section 9 and Table 4).

${ }^{\text {(c) }}$ For $\mathrm{CO}_{2}$ immersion (or submersion as it is called in 10CFR20). 


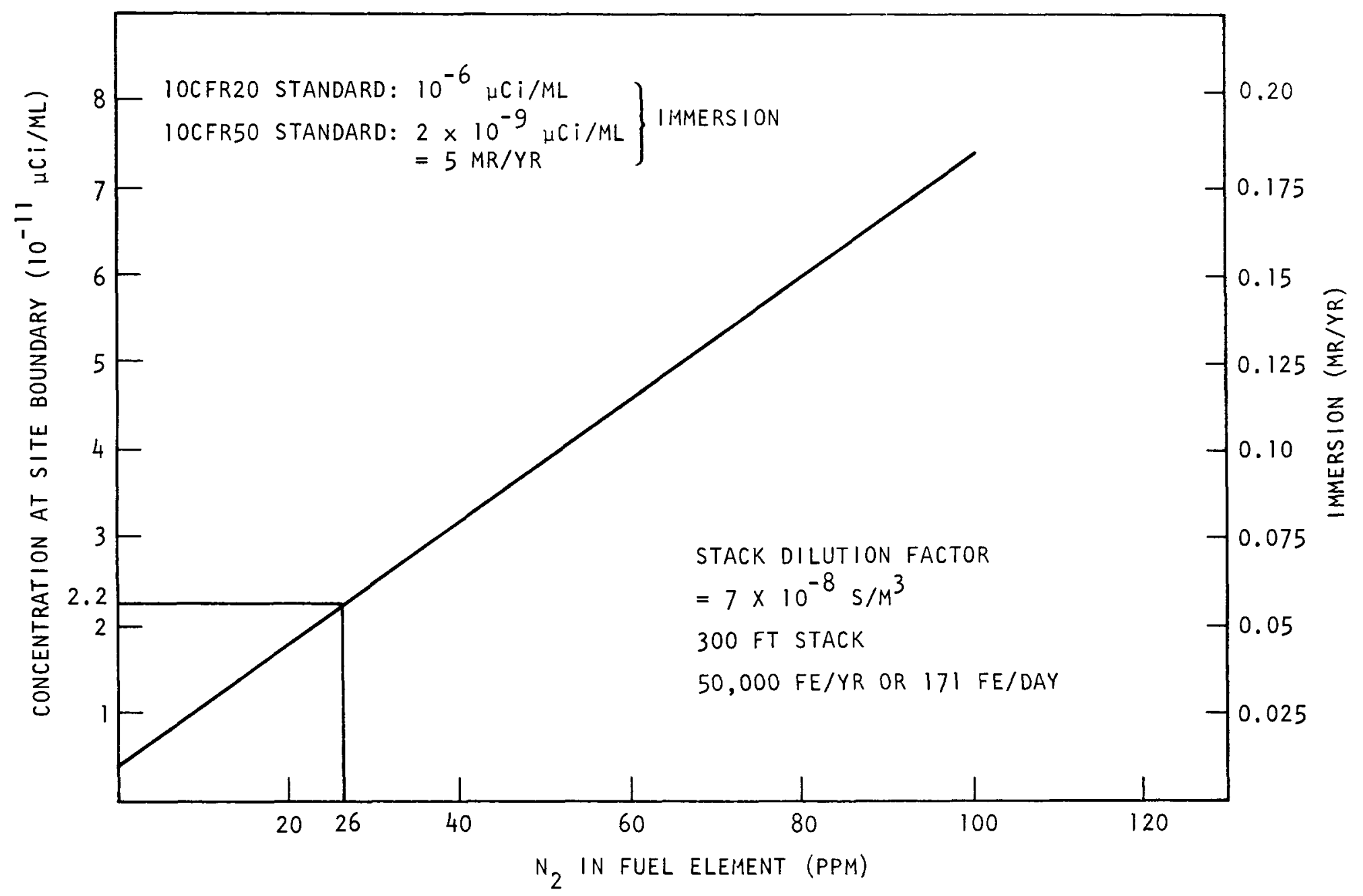

Fig. 4. Activity of $\mathrm{C}-14$ in air at site boundary of HTGR reprocessing plant 
at the site boundary, the man would receive a dose of about $13 \mathrm{mr} / \mathrm{yr}$ (Appendix E). This exceeds the 10CFR50 maximum permissible dose rate of $5 \mathrm{mr} / \mathrm{yr}$. The dose rate at the site boundary will therefore be reduced by increasing the stack height. The average effect of stack height on dilution factor is shown in Fig. 5. Dose rate versus stack height, derived from Fig. 5, is illustrated in Fig. 6. It appears that a suitably high stack (on order of $500 \mathrm{ft}$ ) would enable the boundary C-14 concentration to be reduced below the maximum permissible concentration of $5 \mathrm{mr} / \mathrm{yr}$.

Dose rates for ingestion calculated at ORNL using a 300-ft stack are shown in Table 6 . The total body dose is calculated to be $9 \mathrm{mr}$ compared with 13 nir calculated in this report under apparently identical conditions. The apparent difference is resolved in Appendix $E$. The results relate the potential maximum exposure to individuals at the site boundary to the calculated annual activity release. An individual residing full time near the plant at the location of maximum concentration would receive a maximum dose of $9 \mathrm{mr} / \mathrm{yr}$ to the whole body, $8 \mathrm{mr} / \mathrm{yr}$ to the bone, and $9 \mathrm{mr} / \mathrm{yr}$ to the thyroid. The figure of $9 \mathrm{mr} / \mathrm{yr}$ of whole-body exposure is approximately $7 \%$ of the exposure from natural background radiation ${ }^{*}$ but is twice the maximum permissible concentration (MPC) allowed by 10CFR50. Raising the stack height to $500 \mathrm{ft}$ reduces the dose rate to MPC. The exposures projected for thyroid and bone represent approximately $0.5 \%$ and $0.4 \%$, respectively, of the guideline limits recommended by the Internationa1 Commission on Radiological Protection, Report No. 9.

\section{GLOBAL EFFECT OF ISOLATED INJECTION OF $\mathrm{C}-14$ INTO ATMOSPHERE}

The behavior of $\mathrm{C}-14$ released to the atmosphere has been studied by several investigators using the observed distribution of C-14 from nuclear weapons testing. As discussed in Section 5, tests in the early 1950s added about $550 \mathrm{~kg}$ to the atmosphere and the 1961-1962 tests added approximately

\footnotetext{
The average background radiation in U.S. is estimated to be $130 \mathrm{mr} / \mathrm{yr}$
} (Ref. 12). 


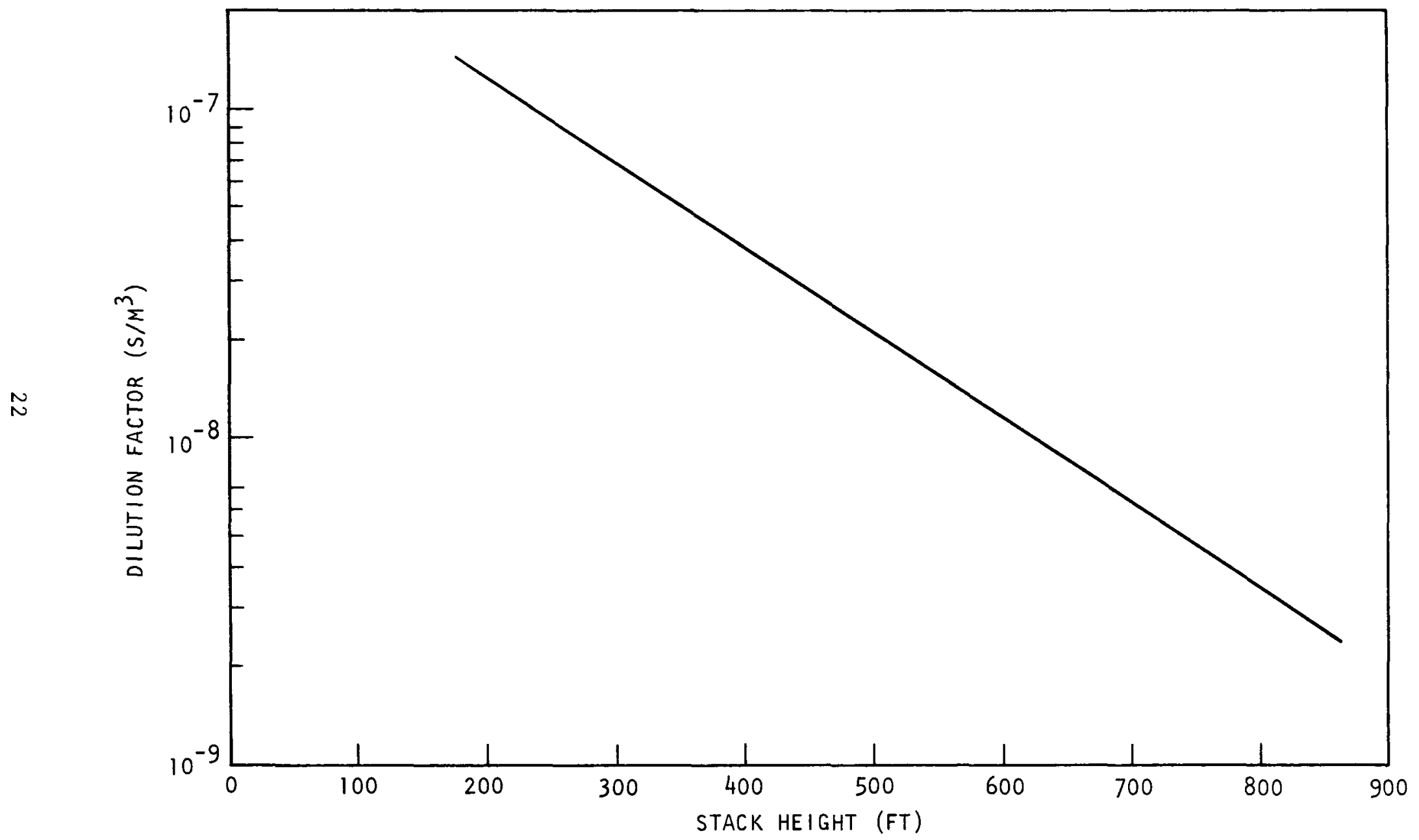

Fig. 5. Relationship between dilution factor and stack height 


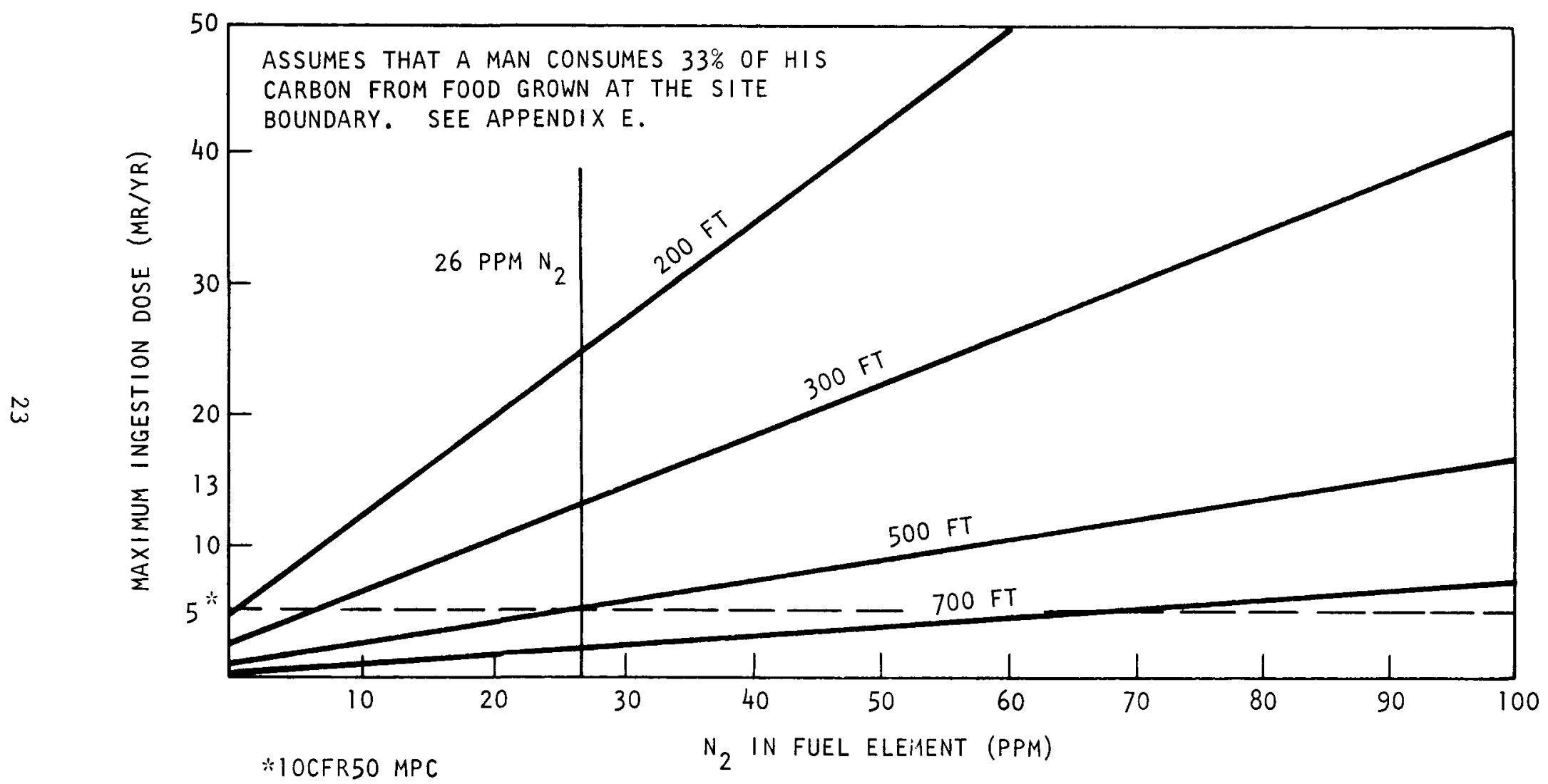

Fig. 6. Estimated maximum ingestion dose from $\mathrm{C}-14$ at boundary of HTGR fuel reprocessing plant using various stack heights 
TABLE 6

SUMMARY OF MAXIMUM INDIVIDUAL DOSES FROM

ROUTINE RELEASES, 300-FT STACK

\begin{tabular}{l|l|l|c}
\hline $\begin{array}{c}\text { Exposure } \\
\text { Pathway }\end{array}$ & $\begin{array}{c}\text { Radioactive } \\
\text { Material }\end{array}$ & \multicolumn{1}{|c|}{ Organ of Preference } & $\begin{array}{c}\text { Annual Dose } \\
\text { Rate (mr/hr) }\end{array}$ \\
\hline Inhalation & H-3 & Lung (a) & 0.16 \\
C-14 & Bone (b) & 0.06 \\
& Pu-238 & Bone (b) & 0.08 \\
C-14 & Total body (c) & 0.01 \\
& Cs & Bone (b) & 0.13 \\
Contaminated ground & Cs & Total body (c) & 0.13 \\
& Cs & Bone (b) & 0.26 \\
& Cotal body (c) & 0.26 \\
Ingestion & C-14 & Bone (b) & 8 \\
& C-14 & Thyroid (d) & 9 \\
& C-14 & Total body (c) & 9 \\
\hline
\end{tabular}

(a) Estimated $100 \mathrm{mr}$ lung dose received annually as result of breathing radiation natura11y occurring in atmosphere (Ref. 12).

(b) Average bone dose of $47 \mathrm{mr}$ received by U.S. residents annually from natural sources of radioactivity (Ref. 12).

(c) Annual whole-body dose received by average U.S. resident from al1 natural sources is $130 \mathrm{mr}$. An estimated 25-million watches containing tritium were sold in U.S. during 1969 and 1970. Whole body doses up to $5.3 \mathrm{mr} / \mathrm{yr}$ result from wearing these watches (Ref. 12).

(d) Estimated dose to thyroid from radioactive fallout was $25 \mathrm{mr} / \mathrm{yr}$ in 1963 and is currently $3 \mathrm{mr} / \mathrm{yr}$ (Ref. 12). 
another $706 \mathrm{~kg}$. Within a few years, the $\mathrm{C}-14$ released into the atmosphere becomes mixed throughout the biosphere including the top layer $(100 \mathrm{~m})$ of the ocean (Ref. 1). Mixing occurs more slowly with the deep layers of the ocean. Since the nuclear explosions occurred in the northern hemisphere, the $\mathrm{C}-14$ concentration became higher than in the southern hemisphere. However, because mixing is constantly occurring, the $\mathrm{C}-14$ concentration in the atmosphere eventually will become uniform. Later it will come to equilibrium with the $\mathrm{C}-14$ in the deep ocean and other carbon reservoirs as does naturally formed C-14; i.e., 1.9\% in the atmosphere and $98.1 \%$ in the remainder of the carbon reservoirs (Table 1). Measurements made from 1955-71 are shown in Fig. 7, which was published by Suess (Ref. 2). It is obvious that the C-14 spilled over from the northern to the southern hemisphere and then began to disappear from the atmosphere. It is not easy to estimate the rate of removal, but Suess considers the residence time to be about 30 years. This suggests a half-life in the atmosphere of about 20 years, if rate is proportional to concentration, but a rough estimate from the graph suggests a half-1ife of about 10 years.

12. GLOBAL EFFECT OF CONTINUING RELEASE OF $\mathrm{C}-14$ TO ATMOSPHERE

Expansion of the HTGR market will result in construction of sufficient reprocessing plants to recover the bred fissile material. If the $\mathrm{C}-14$ is released to the atmosphere, the $\mathrm{C}-14$ inventory will increase as shown in Fig. 4. However, the present $\mathrm{C}-14$ concentration will be constantly reduced by absorption of $\mathrm{C}-14$ into the other reservoirs and the equilibrium of $1.9 \%$ in the atmosphere and $98.1 \%$ in the other reservoirs will try to be achieved. A dynamic situation is thus created in which ever-increasing amounts of $\mathrm{C}-14$ are released to the atmosphere and are countered by ever-increasing amounts being absorbed by the other carbon reservoirs.

This dynamic situation is complicated by the combustion of fossil fuel, which adds large quantities of $\mathrm{C}-12$ to the atmosphere. The effect 
ORNL DWG $73-12785$

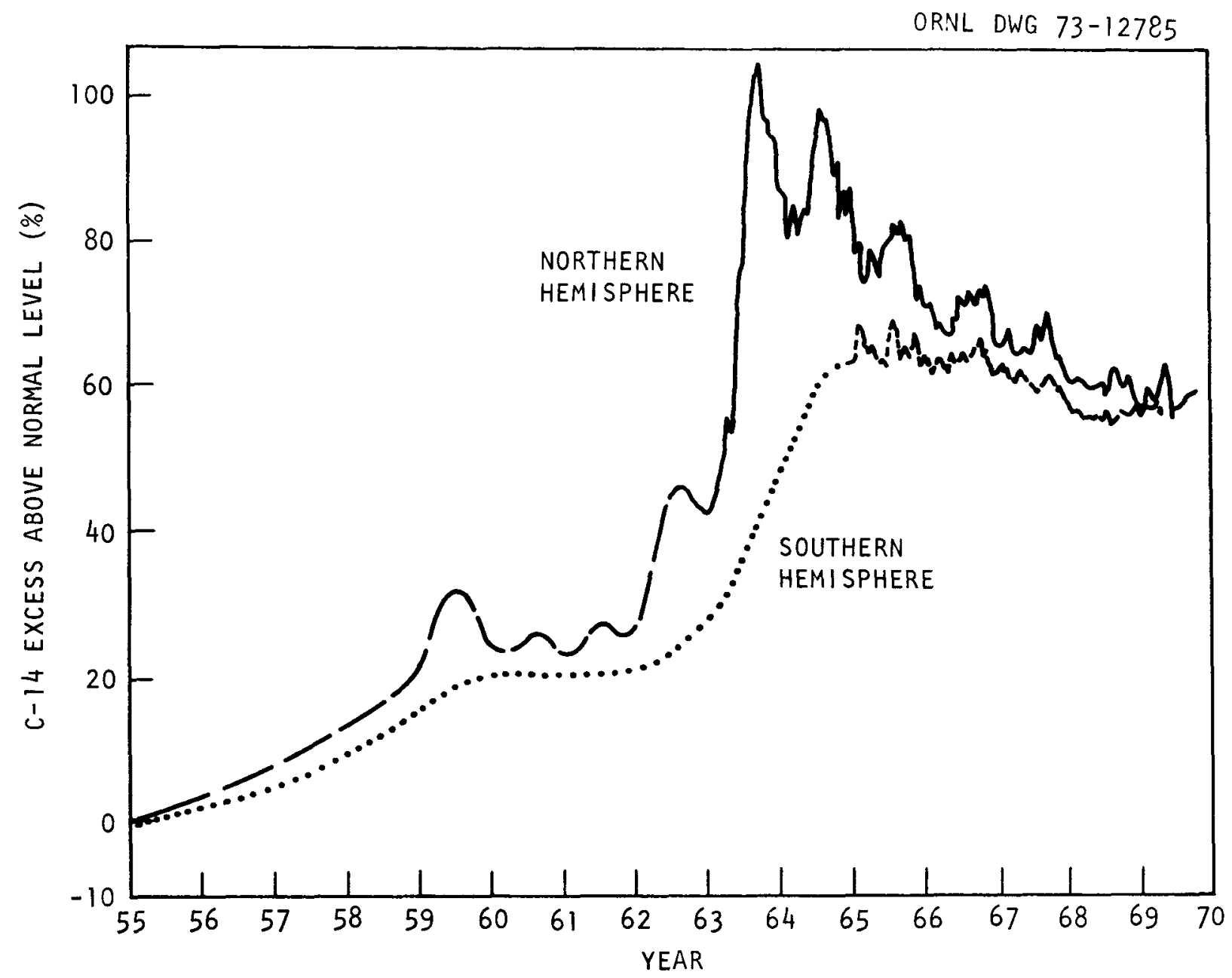

Fig. 7. Disposition of $\mathrm{C}-14$ in atmosphere following bomb tests in 1950 s and 1960s (Ref. 13) 
of this is to greatly reduce the concentration of $\mathrm{C}-14$ in the atmosphere (the Suess Effect). This forecast rate of carbon release is shown in Fig. 8 (Ref. 14).

Flow of carbon between the reservoirs has been studied using differential rate equations to represent movement of carbon among reservoirs and the weight of carbon in each reservoir.

The global carbon transport model (Ref. 4) provides the volumes and flow rates needed for the response calculation, and the additional assumption of we11-mixed carbon reservoirs was made.

The C-14 concentration in Fig. 9 is plotted as kilograms per billion tonnes of $\mathrm{C}-12$. This quantity may be related to $\mathrm{mr} / \mathrm{yr}$ through the generally accepted relation that prior to nuclear weapon testing in 1950, the $\mathrm{C}-14$ exposure due to natural background was $1.6 \mathrm{mr} / \mathrm{yr}$, and the concentration was approximately $1.36 \mathrm{~kg} / 10^{12} \mathrm{~kg}$ (or $13.5 \mathrm{dpm}$ per gram carbon) (see Appendix A).

The $\mathrm{C}-14$ present before man's influence is being diluted by the $\mathrm{C}-12$ in fossil fuel* consumption; this is clearly shown by the broken line in Fig. 9. Because of nuclear weapon testing in the early 1950s through early 1960s, the $\mathrm{C}-14$ concentration approximately doubled. The response calculation predicts that initially the excess $\mathrm{C}-14$ from nuclear weapons will have a half-life of approximately 10 years, but after that the remaining $\mathrm{C}-14$ dies away at a very slow rate.

The $\mathrm{C}-14$ response due to a reprocessing release is based on a nitrogen content of the HTGR core being $26 \mathrm{ppm}$ or $100 \mathrm{ppm}$. The release schedule for the 26-ppm case begins in 1985 and increases to a release of $5.84 \mathrm{~kg}$ of $\mathrm{C}-14$ per year in the year 2000. It is maintained at this value until 2050, when it ceases due to the ending of the HTGR era.

\footnotetext{
*Fossil fuel, because of its age, contains a very low $\mathrm{C}-14$ content (less than $10^{-20}$ times natural), which has a half-life of 5730 years.
} 


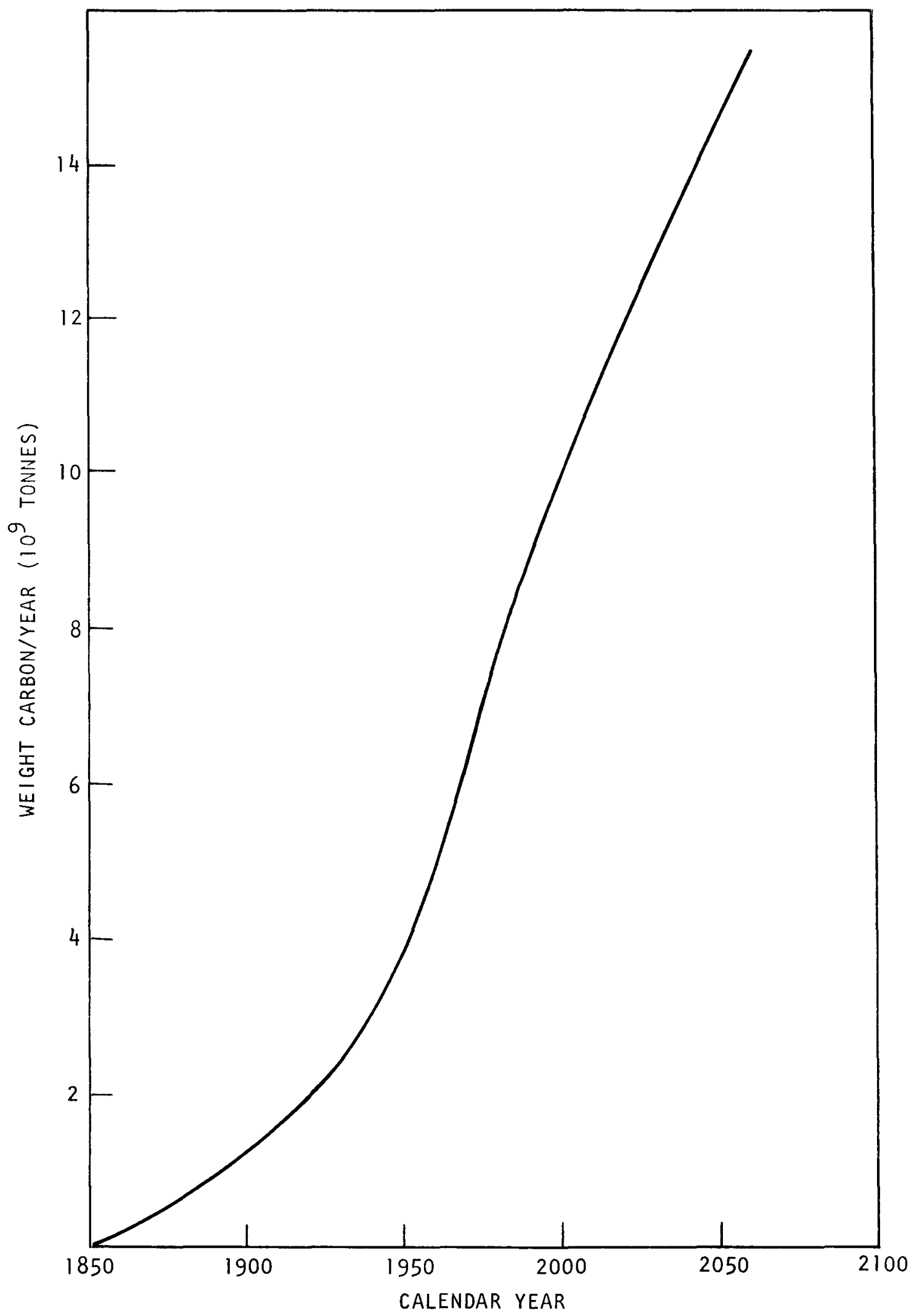

Fig. 8. Projected rate of combustion of fossil carbon (Ref. 14)

28 


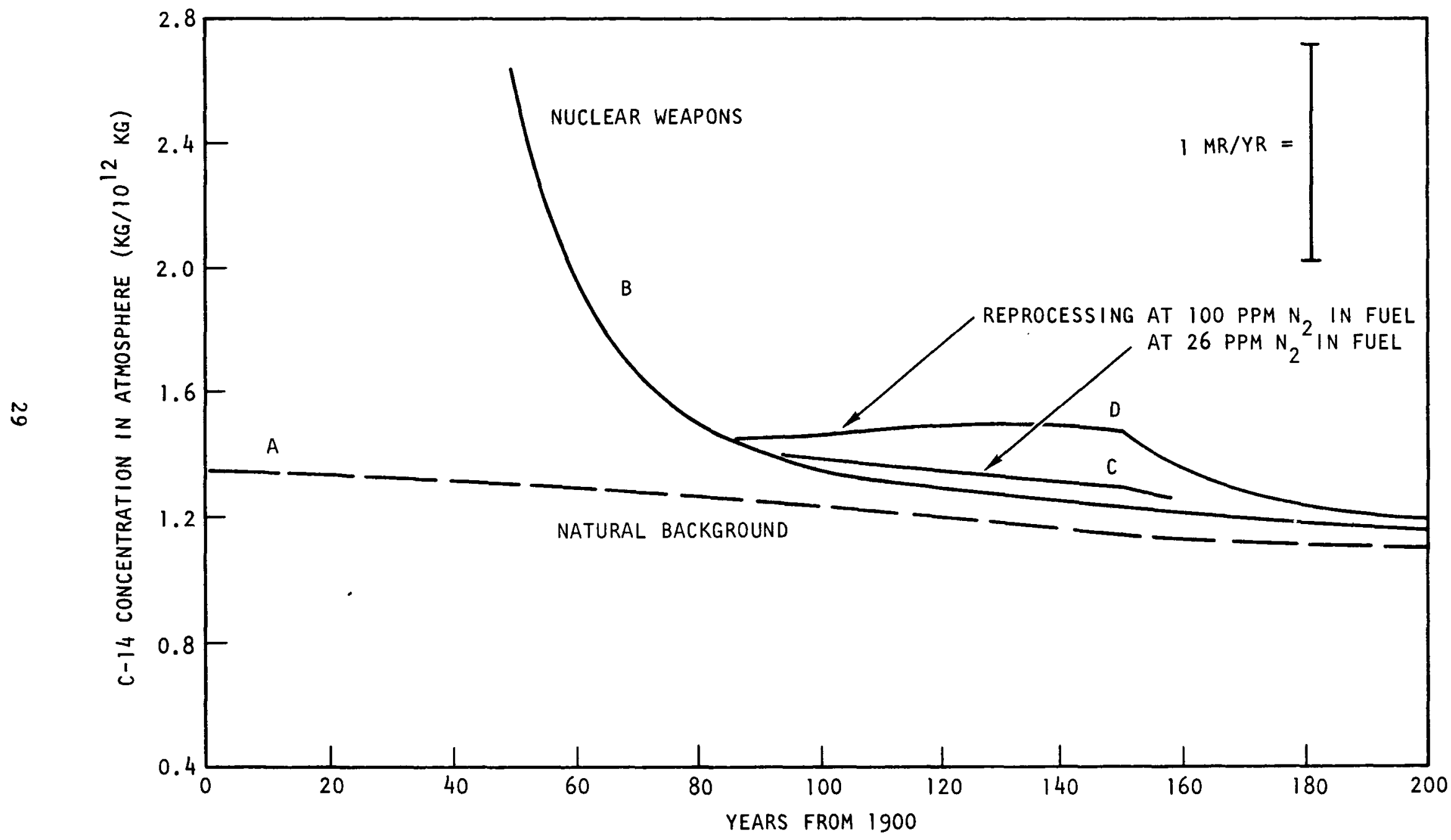

Fig. 9. Global Carbon-14 response 
Due to the assumptions involved in the response calculations, the C-14 responses from various disturbances are additive. For example, if it is desired to obtain the response due to $50 \mathrm{ppm}$ nitrogen in the HTGR core, the response would be one-half that of the $100 \mathrm{ppm}$. This would be represented in Fig. 9 by one-half the distance between the nuclear weapons line and the $100 \mathrm{ppm}$ line.

\section{DOSE COMMITMENT}

The natural background dose to the world population is all-pervading and inescapable if one is to live without radiation shielding. The dose is in two parts: (1) that within the body in the form of $\mathrm{C}-14$ and $\mathrm{K}-40$, and (2) that from the earth and cosmic rays. The sea level dose, which varies over the surface of the earth, is taken to be $130 \mathrm{mr} / \mathrm{yr}$ in the U.S. The total natural background dose is made up as follows:

$$
\begin{array}{ll}
\mathrm{C}-14 & 1.6 \mathrm{mr} / \mathrm{yr} \\
\mathrm{K}-40 & 20.0 \mathrm{mr} / \mathrm{yr} \\
\begin{array}{l}
\text { Earth and } \\
\text { cosmic rays }
\end{array} & \text { approximately } 110 \mathrm{mr} / \mathrm{yr}
\end{array}
$$

The dose received from $\mathrm{C}-14$ and $\mathrm{K}-40$ depends upon the $\mathrm{C}-14 /$ carbon and $\mathrm{K}-40 / \mathrm{K}-39,-41$ ratios in the biosphere since man is in steady state with the biosphere. This dose remains fairly constant per kilogram of body weight.

The earth and cosmic-ray dose varies with latitude, longitude, and altitude. In some parts of the earth, radioactive minerals are exposed or are near the surface, and cause above-background radiation to local inhabitants. If an extra radiation burden is placed in the biosphere by, for example, the operation of a reprocessing plant, the background radiation will increase.

The 1964 UNSCEAR report (Ref. 3) has determined that the dose commitment of $\mathrm{C}-14$ is given by: 


$$
\mathrm{D}_{\infty}=\mathrm{a}_{\mathrm{o}} \frac{\mathrm{Q}}{\mathrm{B}},
$$

where $\mathrm{D}_{\infty}=$ dose commitment over an infinite time,

$$
\begin{aligned}
& \mathrm{a}_{\mathrm{O}}=\text { natural background ingestion dose rate, } 1.64 \mathrm{mr} / \mathrm{yr}, \\
& \mathrm{Q}=\mathrm{kg} \text { of manmade } \mathrm{C}-14 \text { released }, \\
& \mathrm{B}=\text { natural production rate, } \mathrm{kg} / \mathrm{yr} .
\end{aligned}
$$

The equation is in effect saying the extra dose commitment above background is the background rate multiplied by the number of years it would have taken the natural production rate to produce the manmade weight. The release of the nuclear weapon $\mathrm{C}-14$ by the end of 1963 was $1256 \mathrm{~kg}$, and taking the natural production rate of $6.08 \mathrm{~kg} / \mathrm{yr}$ (Appendix B), the dose commitment calculates out at $340 \mathrm{mr}$. (The UNSCEAR report calculates $410 \mathrm{mr}$.)

By 2035 (50 years of HTGR operation), the reprocessing activity will have injected $255 \mathrm{~kg} \mathrm{C}-14$ into the atmosphere, resulting in a dose commitment over an infinite period of time of $69 \mathrm{mr}$ (26 ppm N-14 basis).

The operation of HTGRs is expected to continue for 50 years and the dose commitment during this period has been calculated using the release rates given in Table 4 over the 50 years of 1985 to 2035 . It has been assumed in the calculation that the half-life of excess $\mathrm{C}-14$ in the atmosphere is 33 years as it is absorbed in the ocean (Ref. 15). The dose commitment over 50 years is $7.3 \mathrm{mr}$ (see Appendix F). For comparison, the dose commitment of $\mathrm{C}-14$ in background radiation is $82 \mathrm{mr}$, and of total background radiation, $6500 \mathrm{mr}$.

The value of the dose commitment $(7.3 \mathrm{mr})$ can be used to calculate the number of health effects (Ref. 16). This has been done in Appendix G. The number of health effects is 10,950 over a period of 50 years, which can be compared to the number of health effects of $9.75 \times 10^{6}$ for natura1 background radiation over the same period. 
The natural background level is represented by curve A in Fig. 9. The background level as it stands at the present time is represented by curve B. Curves $\mathrm{C}$ and $\mathrm{D}$ are levels that will occur on releasing $\mathrm{C}-14$ from burning a representative market fuel containing $26 \mathrm{ppm}$ and $100 \mathrm{ppm}$, respectively. The scale on the figure indicates $1 \mathrm{mr} / \mathrm{yr}$. It can be seen, therefore, that in 1985 the extra dose rate of $\mathrm{C}-14$ is zero. For the duration of the market, it is fairly constant at $0.07 \mathrm{mr} / \mathrm{yr}\left(26 \mathrm{ppm} \mathrm{N}_{2}\right.$ ) and then decays away with a half-1ife of 5730 years. In the case of $100 \mathrm{ppm} \mathrm{N}_{2}$, the dose rate rises to $0.36 \mathrm{mr} / \mathrm{yr}$ in 2020 , is constant to 2040, and then decays away with a half-life of 5730 years.

Figure 9 also shows that after 2060 the C-14 level will be less than it was in the year 1900 due to the continuing dilution with fossil carbon (shown in Fig. 8).

\section{FUTURE POSSIBILITIES CONCERNING C-14 RELEASE}

Carbon-14 release to the atmosphere will commence in 1985 with the startup of the HTGR Commercial Reprocessing Plant. The quantity released in the first years will be small because the reprocessing rate will be small. As more HTGRs come on-line and more fuel elements are reprocessed each year, the release rate will increase. It is probable, however, that as fresh fuel production approaches capacity, efforts to reduce the nitrogen level in fuel will pay off. The level will be reduced to less than $26 \mathrm{ppm} \mathrm{N}_{2}$, increased reprocessing throughout will be matched by reduced nitrogen level, and the $\mathrm{C}-14$ release rate will remain constant. Further improvements in fuel manufacture could, during the late 1980s and 1990s, enable the $\mathrm{C}-14$ release to become asymptotic to the level generated by $\mathrm{C}-13(0.03 \mathrm{Ci} / \mathrm{block})$ only if further reduction is required. It is unlikely that attempts to reduce the $\mathrm{C}-14$ release will not be successful and result in a release rate proportional to the HTGR generating capacity.

If $\mathrm{N}-14$ is reduced to zero ppm, the resulting dose from $\mathrm{C}-14$ is reduced to about $20 \%$ of the value where $\mathrm{N}-14$ is assumed to be $26 \mathrm{ppm}$. 


\section{METHODS OF FIXING C-14}

If it is concluded that efforts must be made to limit release of C-14 to the biosphere and that a certain fraction of the release must be fixed, methods for containment must be provided.

15.1. FIXATION AS $\mathrm{CaCO}_{3}$

The reference reprocessing method releases $\mathrm{C}-14$ in the form of $\mathrm{CO}_{2}$ mixed with a large quantity of $\mathrm{CO}_{2}-12$. A possible method of fixation counter currently reacts the $\mathrm{CO}_{2}$ with a slurry of limewater to precipitate $\mathrm{CaCO}_{3}$. The precipitate forms in the water, settles, and is dewatered. The $\mathrm{CaCO}_{3}$, being of very low activity ( $0.55 \mathrm{Ci}$ of soft beta per tonne), could possibly be buried on-site in layers, each layer being covered with blacktop or other waterproof material. Land usage for this purpose would be about 1 acre per year if the $\mathrm{CaCO}_{3}$ were compacted to $901 \mathrm{~b} / \mathrm{ft}^{3}$, which is $50 \%$ of theoretical density. If on-site burial were not permitted, arrangements would have to be made to ship the $\mathrm{CaCO}_{3}$ to a licensed burial ground.

\subsection{BURTAL OF FUEL BLOCK}

If the fuel were completely separated from the block, the block could be cast in concrete in a 55-gal drum and buried on-site (or an alternate licensed burial ground), subject to regulations in force at that time. In this case, land usage would be about the same as above (1 acre per year).

The technical feasibility of obtaining the required levels of separation by these methods remains to be determined. In order to meet the requirements of the "as low as practicable" regulation, it will be 
necessary to perform a cost-benefit analysis of this potential method.

At the present time, however, sufficient data to perform such an analysis are not available. 
16. CONCLUSIONS

1. During HTGR reactor operation, $\mathrm{C}-14$ is formed in the fuel elements mainly from nitrogen, which is an impurity in the fuel-element components. The nuclear reaction is $n, p$ with the nitrogen that is not outgassed or desorbed from the fuel element. Calculations show that each ppm of nitrogen results in $0.005 \mathrm{Ci}$ of $\mathrm{C}-14$ per fuel element after 4 years in the reactor. A secondary source of $\mathrm{C}-14$ is the $\mathrm{n}, \mathrm{Y}$ reaction of $\mathrm{C}-13$, which exists naturally in carbon to a concentration of $1.11 \%$. Calculations show that this quantity results in $0.03 \mathrm{Ci}$ of C-14 per fuel element after 4 years in the reactor.

2. Although $\mathrm{C}-14$ production can be reduced by excluding nitrogen-bearing materials from the fuel element components, the production of $\mathrm{C}-14$ from $\mathrm{C}-13$ cannot be influenced because the natural concentration of $\mathrm{C}-13$ in carbon is constant. This means that even if the nitrogen content of the fuel element can be reduced to zero, the final C-14 will never be less than $0.03 \mathrm{Ci}$ per fuel element.

3. As more HTGRs are brought on line, the fuel elements will be reprocessed at an increasing rate and the $\mathrm{C}-14$ released from the burning operation will continue to increase until no more reactors are brought on line. During the era of HTGRs from 1985 to 2035, the C-14 quantity (assuming $26 \mathrm{ppm}$ nitrogen) will rise to $5.85 \mathrm{~kg} / \mathrm{yr}$ in the year 2000 and will remain constant for 35 years resulting in an accumulated mass of $255 \mathrm{~kg}$. This can be compared with $953 \mathrm{~kg}$ continuously maintained in the atmosphere by the natural generation rate of $6.08 \mathrm{~kg} / \mathrm{yr}$, and with $50,300 \mathrm{~kg} \mathrm{C}-14$ on the earth. The atmospheric quantity $953 \mathrm{~kg} \mathrm{C}-14$ formed in the upper atmosphere eventually enters the carbon cycle and, therefore, into edible vegetation leading to a radiological dose rate of $1.64 \mathrm{mr} / \mathrm{yr}$.

4. Carbon-14 is formed in the atmosphere and eventually finds its way via the carbon cycle into the oceans where it decays with a half-life of 5730 years. The rate of transport from the atmosphere to the 
ocean has been continually monitored following the atom bomb C-14 release in the 1950s. $\mathrm{C}-14$ is found to be transferring from the atmosphere to the ocean with a half-1ife from 10 to 33 years. This means that released $\mathrm{C}-14$ is removed from the atmosphere relatively rapidly. The global steady state value of $\mathrm{C}-14$ in the atmosphere is $1.9 \%$.

5. Some samples of irradiated graphite were examined quantitatively for $\mathrm{C}-14$. The results showed that the $\mathrm{C}-14$ concentration in the samples was equivalent to 6 to $12 \mathrm{ppm}$ of nitrogen concentration in the fuel element during irradiation. The C-14 content of other fuel components has not been measured.

6. If a11 the C-14 from a typical HTGR fuel element assumed to contain $26 \mathrm{ppm}$ nitrogen were released to the atmosphere from a reprocessing plant of 57,500 blocks/year throughput, the site boundary immersion dose rate would be $0.05 \mathrm{mr} / \mathrm{yr}$. This dose rate is accumulated by being in the atmosphere at the boundary for one year. The ingestion dose rate, accumulated by $\mathrm{C}-14$ being digested following consumption of one-third of the food grown at the site boundary, is $5 \mathrm{mr} / \mathrm{yr}$ using a 500-ft stack. Regulations in 10CFR50 restrict the site boundary dose rate to $5 \mathrm{mr} / \mathrm{yr}$.

7. The combustion of fossil fuel, which because of its great age contains no $\mathrm{C}-14$, dilutes the $\mathrm{C}-14$ in the atmosphere. The background radiation level due to ingested $\mathrm{C}-14$ depends on the concentration of $\mathrm{C}-14$ in atmospheric carbon and hence is reduced by fossil fuel combustion.

8. The ingestion dose commitment due to $\mathrm{C}-14$ being released during the HTGR era is estimated to be $7.3 \mathrm{mr}$ during the 50-year period 1985 to 2035. This compares with the sea level background dose commitment of $6500 \mathrm{mr}$ over the same period. This dose commitment does not take into account the reduction in $\mathrm{C}-14$ dose commitment due to the combustion of fossil fuel. The infinite ingestion dose commitment due to $\mathrm{C}-14$ released during the 50-year era of HTGRs is $69 \mathrm{mr}$. This compares with $3.7 \times 10^{10} \mathrm{mr}$ for $\mathrm{K}-40$, which is a constituent of a11 biologica1 materials. 
9. Radiation is regarded as harmful no matter how low the dose rate. The harmful effect is quantified in a number known as the health effect. For $\mathrm{Kr}-85$ there are 300 health effects per $10^{6}$ man-rem. If the harmful effect is the same for $\mathrm{C}-14$ as for $\mathrm{Kr}-85$, the health effect over the 50-year HTGR era would be 10,950, which compares with the health effect rate due to natural background radiation of 190,000 per year, or $9.7 \times 10^{6}$ over 50 years. 


\section{RECOMMENDATIONS}

1. To gain a better understanding of the source of $\mathrm{C}-14$ in a reprocessing facility, measure the $\mathrm{C}-14$ content of irradiated HTGR fuel components (graphite, matrix, pyrocarbon, buffer carbon, and kernels). (GA, ORNL)

2. Establish a program to determine the absorption/desorption characteristics of nitrogen in fuel element components to determine the amount of nitrogen that will be irradiated and converted to $\mathrm{C}-14$. (GA)

3. Examine the relationship between Recommendation 1 and Recommendation 2 .

4. Define the methods that will reduce the residual nitrogen that appears in fuel element components during manufacture for the purpose of conducting a cost-benefit analysis of the methods.

5. Explore methods of separating the fuel from the fuel block. If one or the other does not contain any $\mathrm{C}-14$, the components might be processed separately with no or minimum release of $\mathrm{C}-14$.

6. Investigate methods of fixation of the carbon present in the $\mathrm{CO}_{2}$. (ORNL) 
APPENDIX A

WEIGHT OF C-14 IN ATMOSPHERE AND OTHER VALUES

IN 1952 (PRIOR TO BOMB TESTS)

1. Volume concentration of carbon in atmosphere is $320 \mathrm{ppm}$ (Refs. 18,19).

2. Activity of $\mathrm{C}-14$ in carbon in atmosphere is $13.5 \mathrm{dpm}$ per $\mathrm{gC}$ (Refs. 20-24).

3. 1 Curie $=2.22 \times 10^{12} \mathrm{dpm}$.

4. Specific activity of $\mathrm{C}-14=4.46 \mathrm{Ci} / \mathrm{g}$.

5. Depth of atmosphere at $1 \mathrm{~atm}=8.620 \mathrm{~m}$.

6. Area of surface of earth $=5.1 \times 10^{14} \mathrm{~m}^{2}$.

Weight of carbon $/ \mathrm{m}^{3}$ at $20^{\circ} \mathrm{C}=\frac{320 \mathrm{~cm}^{3} \mathrm{gmole}}{\mathrm{m}^{3} 22,400 \mathrm{~cm}^{3}} \times \frac{12 \mathrm{~g}}{\mathrm{gmole}} \times \frac{273}{293}=0.16 \mathrm{~g} / \mathrm{m}^{3}$.

Activity of $\mathrm{C}-14$ in air $=\frac{13.5}{2.22 \times 10^{12}} \frac{\mathrm{dpm} \mathrm{Ci}}{\mathrm{g} \mathrm{dpm}} \times \frac{0.16 \mathrm{~g}}{1 \mathrm{~m}^{3}}=9.7 \times 10^{13} \frac{\mathrm{Ci}}{\mathrm{m}^{3}}$.

Weight of $\mathrm{C}-14$ in air $=9.7 \times 10^{-13} \frac{\mathrm{Ci}}{\mathrm{m}^{3}} \times \frac{1 \mathrm{~g}}{4.46 \mathrm{Ci}}=2.17 \times 10^{-13} \mathrm{~g} \mathrm{C}-14 / \mathrm{m}^{3}$.

Volume of atmosphere $=5.1 \times 10^{14} \mathrm{~m}^{2} \times 8620 \mathrm{~m}=4.4 \times 10^{18} \mathrm{~m}^{3}$.

Weight of $\mathrm{C}-14$ in atmosphere $=4.4 \times 10^{18} \mathrm{~m}^{3} \times 2.17 \times 10^{-13} \mathrm{~g} \mathrm{C}-14 / \mathrm{m}^{3}$

$$
=954 \mathrm{~kg} .
$$

Concentration of $\mathrm{C}-14$ in atmospheric carbon $=13.5 \frac{\mathrm{dpm}}{\mathrm{g}} \times \frac{\mathrm{Ci}}{2.22 \times 10^{12} \mathrm{dpm}}$

$$
\mathrm{x} \frac{1 \mathrm{~g}}{4.46 \mathrm{Ci}}=1.36 \times 10^{-12} \mathrm{~g} / \mathrm{g} .
$$


Activity of $\mathrm{C}-14$ in air $=9.7 \times 10^{-13} \mathrm{Ci} / \mathrm{m}^{3}$.

Weight of $\mathrm{C}-14$ in atmosphere $=954 \mathrm{~kg}$.

Concentration of $\mathrm{C}-14$ in air $=2.17 \times 10^{-13} \mathrm{~g} / \mathrm{m}^{3}$.

Concentration of $\mathrm{C}-14$ in atmospheric carbon $=1.36 \times 10^{-12} \mathrm{~g} / \mathrm{g}$. 
APPENDIX B

NATURAL PRODUCTION RATE OF C-14

The natural production rate is calculated as follows:

1. Average activity ${ }^{*}$ of $\mathrm{C}-14$ in carbon throughout earth $=11.86 \pm 1 \mathrm{dpm}$.

2. Specific activity of $\mathrm{C}-14=4.46 \mathrm{Ci} / \mathrm{g}$.

3. $\mathrm{Ci}=2.22 \times 10^{12} \mathrm{dpm}$.

4. Weight of carbon in the earth $=42 \times 1015 \mathrm{~kg}$.

5. Half-1ife of $\mathrm{C}-14=5730$ years.

Then weight of $\mathrm{C}-14$ in the earth is given by

$$
\begin{aligned}
42 \times 10^{15} \mathrm{~kg} \times & 11.86 \frac{\mathrm{dpm}}{\mathrm{g}} \times \frac{\mathrm{Ci}}{2.22 \times 10^{12} \mathrm{dpm}} \times \frac{\mathrm{g}}{4.46 \mathrm{Ci}} \\
= & 50,300 \mathrm{~kg} .
\end{aligned}
$$

Then the rate is given by the decay equation

$$
\frac{\mathrm{dc}}{\mathrm{dt}}=\lambda \mathrm{c}=\frac{-0.693}{5730} \times 50,300=6.08 \mathrm{~kg} / \mathrm{yr}
$$

Natural Rate $=6.08 \mathrm{~kg} / \mathrm{yr}$.

The numbers calculated depend on the input numbers, which vary slight1y among authors.

\footnotetext{
*Atmospheric activity is $13.5 \mathrm{dpm}$ but activity in ocean is less because residence time of $\mathrm{C}-14$ is long and it is decaying away. $* *$

The concentration of $\mathrm{C}-14$ on the earth has been virtually constant for years (Ref. 1).
} 
APPENDIX C

IMMERSION AND INGESTION DOSE RATE

DUE TO C-14 IN ATMOSPHERE

Energy of disintegration of $\mathrm{C}-14=0.156 \mathrm{MeV}$.

Then:

Specific dose rate (immersion) $=$

$$
\begin{gathered}
\frac{0.1 \mathrm{erg}}{\mathrm{mr} g(\mathrm{air})} \times \frac{10^{6} \mathrm{MeV}}{1.6 \mathrm{erg}} \times \frac{1 \mathrm{~d}}{0.156 \mathrm{MeV}} \times \frac{1 \mathrm{yr}}{365 \times 24 \times 3600 \mathrm{~s}} \times \frac{\mathrm{g}(\mathrm{air})}{1200 \mathrm{~cm}} \\
\times \frac{1 \mathrm{~S} \mu \mathrm{Ci}}{3.70 \times 10 \mathrm{~d}}=2.87 \times 10^{-10 \frac{\mu \mathrm{Ci} \mathrm{yr}}{\mathrm{cm}^{3} \mathrm{mr}}} .
\end{gathered}
$$

Dose rate due to $\mathrm{C}-14$ in air (immersion) $=0.0034 \mathrm{mr} / \mathrm{yr}$.

Ingestion dose rate due to equilibrating with atmospheric C-14

$$
1.64 \mathrm{mr} / \mathrm{yr}=9.7 \times 10^{-13} \mu \mathrm{Ci} / \mathrm{ml}
$$

Therefore

$$
5 \mathrm{mr} / \mathrm{yr}=2.96 \times 10^{-12} \mu \mathrm{Ci} / \mathrm{ml}
$$

\section{Conversion Factors}

Immersion: $1 \mathrm{mr} / \mathrm{yr}=2.87 \times 10^{-10} \mu \mathrm{Ci} / \mathrm{ml}$.

Ingestion: $1 \mathrm{mr} / \mathrm{yr}=5.9 \times 10^{-13} \mu \mathrm{Ci} / \mathrm{ml}$. 


\section{APPENDIX D}

C-14 CONCENTRATION IN ATMOSPHERE AT SITE BOUNDARY

(26 ppm $\mathrm{N}_{2}$ assumed)

1. Plant capacity $=50,000 \mathrm{FE} / \mathrm{yr}$.

2. On-stream time $=292$ days $/ y r$.

3. Stack height $=300 \mathrm{ft}$.

4. Dilution factor $=7 \times 10^{-8} \mathrm{~s} / \mathrm{m}^{3}$.

Annual release $=50,000 \mathrm{FE} \times \frac{0.16 \mathrm{Ci}}{\mathrm{FE}}=8,000 \mathrm{Ci}$.

Site boundary concentration is given by:

$$
\begin{gathered}
8000 \frac{\mathrm{C} i}{\mathrm{yr}} \times \frac{\mathrm{y}}{292 \mathrm{~d}} \times \frac{\mathrm{d}}{24 \mathrm{~h}} \times \frac{\mathrm{h}}{3600 \mathrm{~s}} \times 7 \times 10^{-8} \frac{\mathrm{s}}{\mathrm{m}^{3}} \\
\quad=2.2 \times 10^{-11} \mathrm{\mu Ci} / \mathrm{ml} .
\end{gathered}
$$

Boundary concentration $=2.2 \times 10^{-11} \mu \mathrm{Ci} / \mathrm{ml}$. 
APPENDIX E

INGESTION OF C-14 AT SITE BOUNDARY (300-FT STACK)

1. Man consumes $33 \%$ of his carbon from sources at steady state with site boundary $\mathrm{C}-14$ concentration.

2. 300-ft stack + dilution factor of $7 \times 10^{-8} \mathrm{~s} / \mathrm{m}^{3}$.

3. C-14 dose to human body is $1.64 \mathrm{mr} / \mathrm{yr}^{*}$ (Section 4 ).

4. Assume dose rate is proportional to the $\mathrm{C}-14$ concentration.

5. Background concentration of $\mathrm{C}-14$ in air is $9.7 \times 10^{-13} \mathrm{Ci} / \mathrm{m}^{3}$ (Appendix A).

6. Concentration at site boundary $=2.2 \times 10^{-11} \mathrm{Ci} / \mathrm{m}^{3}$ (Appendix D).

Then dose rate $\mathrm{D}$ is given by proportionality:

$$
\frac{\left(0.33 \times 2.2 \times 10^{-11}+0.67 \times 9.7 \times 10^{-13}\right)}{9.7 \times 10^{-13}}=\frac{\mathrm{D}}{1.64} .
$$

Dose rate $=13 \mathrm{mr} / \mathrm{yr}$.

Dose rate using Hamilton's data (Ref. 5) before applying uncertainty factors

$$
=\frac{\left(0.33 \times 1.6 \times 10^{-11}+0.67 \times 9.7 \times 10^{-13}\right)}{9.7 \times 10^{-13}}=\frac{\mathrm{D}}{1.64} .
$$

Dose rate $=10 \mathrm{mr} / \mathrm{yr}$ (very close to ORNL value of $9 \mathrm{mr} / \mathrm{yr}$; Section 10 ).

\footnotetext{
* Dose rate in 1952 was estimated to be $1.64 \mathrm{mr} / \mathrm{yr}$ and in 1962
}

$3.7 \mathrm{mr} / \mathrm{yr}$ after bomb tests. Total average background in U.S. is estimated to be $130 \mathrm{mr} / \mathrm{yr}(\operatorname{Ref} .12)$. 


\section{APPENDIX $\mathrm{F}$}

CALCULATION OF C-14 DOSE COMMITMENT OVER 50 YEARS

$$
\text { (1 } \mathrm{FE} \equiv 0.16 \mathrm{Ci})
$$

\begin{tabular}{|c|c|c|c|c|c|c|}
\hline$\underline{Y r}$ & $\begin{array}{l}\text { No. of } \\
\text { FEs }\left(10^{3}\right) \\
\end{array}$ & $\begin{array}{l}\text { Incremental } \\
\text { FEs }\left(10^{3}\right) \\
\end{array}$ & $\begin{array}{l}\text { Incremental Dose } \\
\text { Rate R }\left(10^{3} \mathrm{Ci} / \mathrm{yr}\right) \\
\end{array}$ & $\begin{array}{l}\text { Years of } \\
\text { Exposure }\end{array}$ & $\begin{array}{l}\text { Incremental } \\
\text { Dose Commt } \\
\left(10^{3} \mathrm{Ci}\right) \\
\end{array}$ & $\begin{array}{c}\text { Cum Dose } \\
\text { Commitment } \\
\left(10^{3} \mathrm{Ci}\right) \\
\end{array}$ \\
\hline 0 & 0 & 0 & 0 & 50 & 0 & 0 \\
\hline 1 & 25 & 25 & 4.0 & 49 & 3,504 & 3,504 \\
\hline 3 & 32 & 7 & 1.1 & 47 & 897 & 4,401 \\
\hline 5 & 52 & 20 & 3.2 & 45 & 2,421 & 6,823 \\
\hline 7 & 71 & 19 & 3.0 & 43 & 2,098 & 8,921 \\
\hline 9 & 89 & 18 & 2.9 & 41 & 1,866 & 10,786 \\
\hline 11 & 114 & 25 & 4.0 & 39 & 2,357 & 13,143 \\
\hline 13 & 133 & 44 & 7.0 & 37 & 3,758 & 10,901 \\
\hline 15 & 152 & 19 & 3.0 & 35 & 1,459 & 18,361 \\
\hline 17 & 163 & 11 & 1.7 & 33 & 744 & 19,105 \\
\hline & 163 & 0 & 0 & & & \\
\hline 49 & 163 & 0 & 0 & 0 & & \\
\hline
\end{tabular}

Volume of atmosphere $=4.4 \times 10^{18} \mathrm{~m}^{3}$.

Concentration $=\frac{19.1 \times 10^{6}}{4.4 \times 10^{18}} \cdot \frac{\text { Ciy }}{\mathrm{m}^{3}}=4.3 \times 10^{-12} \frac{\text { Ciy }}{\mathrm{m}^{3}}$.

But $\frac{1 \text { Ciy }}{\mathrm{m}^{3}}=1.69 \times 10^{9} \mathrm{rem}$.

Dose commitment $=7.3 \mathrm{mr}$ over 50 years of operation.

$$
\text { * Dose commitment } \left.=\frac{\mathrm{Rt}}{\lambda}-\frac{\mathrm{R}}{\lambda^{2}}\left(1-\mathrm{e}^{-\lambda t}\right) \quad \text { (half } \text { life } \equiv 33 \text { years }\right) .
$$




\section{APPENDIX G \\ HEALTH EFFECTS OVER 50 YEARS DUE TO \\ C-14 RELEASE FROM HTGR REPROCESSING}

Dose commitment for C-14 is $7.3 \mathrm{mr}$ over 50 years (1985 to 2035).

Health effects (HE) due to $\mathrm{Kr}-85$ are given as 300 per $10^{6}$ man-rem exposure (Ref. 16). If this number is the same for $\mathrm{C}-14$, the health effects can be calculated as follows:

World population $=5 \times 10^{9}$ man.

Health effects $=\frac{7.3 \times 10^{-3} \mathrm{rem}}{10^{6} \text { man-rem }} \times \frac{300 \mathrm{HE}}{1} \times \frac{5 \times 10^{9} \mathrm{man}}{1}$.

Hea1th Effects $=10,950$ due to $C-14$ over 50 years.

Total background HEs are given by:

$0.130 \frac{\mathrm{rem}}{\mathrm{yr}} \times 50$ yr $\times \frac{300 \mathrm{HE}}{10^{6} \text { man-rem }} \times \frac{5 \times 10^{9} \mathrm{man}}{1}$.

$\underline{\mathrm{HE}}=9.75 \times 10^{6}$ due to background radiation over 50 years. 


\section{REFERENCES}

1. Fairha11, A. W., and J. A. Young, "Radiocarbon in the Environment: Radio-nuclides in the Environment, Advances in Chemistry Series No. 95," Amer. Chem. Soc. 1970, pp. 401-418.

2. Suess, H. E., Proceedings of the XII Nobel Symposium on Radiocarbon Variations and Absolute Chronology, 303, 595; 1969.

3. United Nations Scientific Committee on the Effects of Atomic Radiation, 19 th Session, Supplement No. 14 (A/5814), New York, 1964.

4. Cramer, J. J., "Mathematical Models of Chemical Pollution of the Environment," Univ. of Pennsylvania, Ph. D. thesis in Chemical Engineering, 1971.

5. Hamilton, C. J., General Atomic Company, "Expected C-14 Production in the HTGR," unpublished data, 1973.

6. Roberts, D. G., General Atomic Company, "C-14 in the HTGR Cycle," unpublished data, January 17, 1974.

7. Brooks, L. H., General Atomic Company, private communication from GEGB in the UK, 1974 .

8. Crockett, T., et a1., Genera1 Atomic Company, "Carbon-14 Determination in OG-1 Irradiated Graphite," unpublished data, August 1974.

9. Mosen, A., General Atomic Company, "Nitrogen Content of Fuel Particles," unpublished data, November 1972.

10. Snider, J., Oak Ridge National Laboratory, private communication, 1974.

11. "Data on the ORIGEN Code," Oak Ridge National Laboratory Report ORNL-TM-4360, to be published.

12. Klements, A. W., et al.," Estimates of Ionizing Radiation Doses in the United States, 1960-2000," U.S. Environmental Protection Agency (ORP/SCD 72-1), August 1972.

13. Vogel, J. C., and M. Marais," Pretoria Radiocarbon Dates I," Radiocarbon 13, 378-394 (1971).

14. Bolin, B., "The Carbon Cycle," Scientific American, 223:125, 1970.

15. Houtermans, J. C., and H. E. Suess, "Reservoir Models and Production Rate Variations of Natural Radiocarbon," J. Geoph. Res. 78, p 1897, 1973. 
16. "Environmental Analysis of the Uranium Fuel Cycle, Part III," Environmental Protection Agency Report EPA-520/9-73-003-D, October 1973.

17. Brooks, L. H., "Progress in the Thorium/U-233 Shipping, Reprocessing, and Refabrication Technology," General Atomic Company Report GA-A13064, July 1974 .

18. Handbook for Chiemistry \& Physics, Chemical Rubber Publishing Co., 1961.

19. Handbook for Chemistry and Physics, Chemical Rubber Publishing Co., 1970, 51st Edition.

20. Broecker, W. S., et al., "Radiocarbon Analysis of Oceanic Carbon Dioxide," Intern. J. App1. Radiation Isotopes 7,1 (1959).

21. Ferguson G. J., "Radiocarbon Dating System," Nucleonics, 13,18 (1955).

22. Hayes, F. N., et a1., 'Liquid Scintillation Counting of Natural Carbon-14," Phys. Rev. 92, 512 (1953).

23. Libby, W. F., Radiocarbon Dating, 2nd Ed., University of Chicago Press, Chicago, 1955.

24. Suess, H. E., "Radiocarbon Concentration in Modern Wood," Science, 122, 415 (1955). 